\title{
Méditerranée
}

Revue géographique des pays méditerranéens / Journal of Mediterranean geography

$130 \mid 2018$

Portugal, a country in transformation

\section{Portugal as a tourism destination}

Paths and trends

Le Portugal en tant que destination touristique. Trajectoires et tendances

\section{Claudete Oliveira Moreira}

\section{(2) OpenEdition}

12 Journals

\section{Electronic version}

URL: http://journals.openedition.org/mediterranee/10402

DOI: 10.4000/mediterranee.10402

ISSN: $1760-8538$

Publisher

Presses Universitaires de Provence

Brought to you by Aix-Marseille Université (AMU)

\section{Aix Marseille universite}

Electronic reference

Claudete Oliveira Moreira, « Portugal as a tourism destination », Méditerranée [Online], 130 | 2018,

Online since 28 November 2018, connection on 15 January 2019. URL : http://

journals.openedition.org/mediterranee/10402; DOI : 10.4000/mediterranee.10402

This text was automatically generated on 15 January 2019.

Tous droits réservés 


\title{
Portugal as a tourism destination
}

\author{
Paths and trends
}

Le Portugal en tant que destination touristique. Trajectoires et tendances

Claudete Oliveira Moreira

This work was co-financed by the European Regional Development Fund (ERDF) through the COMPETE 2020-Operational Program Competitiveness and Internationalization (POCI)-and national funds by FCT under the POCI-01-0145-FEDER-006891 project (FCT Ref: UID / GEO 04084/2013).

\section{1 - The Socio-Economic Relevance of Tourism in Portugal}

1 Portugal is part of what is the main region of tourist destinations worldwide: Europe, more specifically, Mediterranean Europe. Located in the Iberian Peninsula at the extreme southwest of the continent, Portugal is composed of the mainland area-a territory whose border is the oldest and most stable in the world, having been in place for over 7 centuries, in a country that has existed for almost 9 centuries-and by two Atlantic Archipelagos: Madeira and the Azores. To the Portuguese-Spanish land border (about $1,319 \mathrm{~km}$ long) we can add mainland Portugal's long coastline, which is $1,240 \mathrm{~km}$ of contact with the Atlantic Ocean. In its relatively small territory Portugal has a wide diversity of landscapes, natural parks, historical, architectural, cultural and religious monuments, intangible cultural expressions, culinary traditions, wine regions, historical villages, spas, golf courses, ports and marinas, waterways, lakes, reservoirs with piers and moorings, providing different, unique experiences within easy reach.

In terms of tourist destinations there has been investment in upgrading, innovation, sustainability and internationalization, with the destination's facilities often winning awards. In 2002 the 9thedition of the World Travel Awards distinguished an accommodation establishment in Portugal for the first time. In their last edition in 2017, Portugal was singled out as the World's Leading Destination. It was also awarded several other distinctions: Europe's Leading Destination, and Europe's Leading Beach Destination. 
O Turismo de Portugal, the national tourist authority was deemed World's Leading Tourist Board, Europe's Leading Tourist Board and World's Leading Tourism Authority Website [ online]. In the same year Lisbon was considered World's Leading City Break Destination.

3 In 2016, Portugal won 24 awards and a lot of tourist enterprises won awards, Turismo de Portugal, was deemed Europe's Leading Tourist Board; Lisbon was considered Europe's Leading Cruise Destination and Lisbon's Port as Europe's Leading Cruise Port; the Algarve was singled out as Europe's Leading Beach Destination; Madeira as Europe's Leading Island Destination. Passadiços do Paiva (Arouca UNESCO Global Geopark [online] was deemed Europe's Leading Tourism Development Project in 2016 and in 2017 (Fig. 1 and Fig. 2).

Fig. 1 - Passadiços do Paiva (Paiva Walkways), Arouca UNESCO Global Geopark

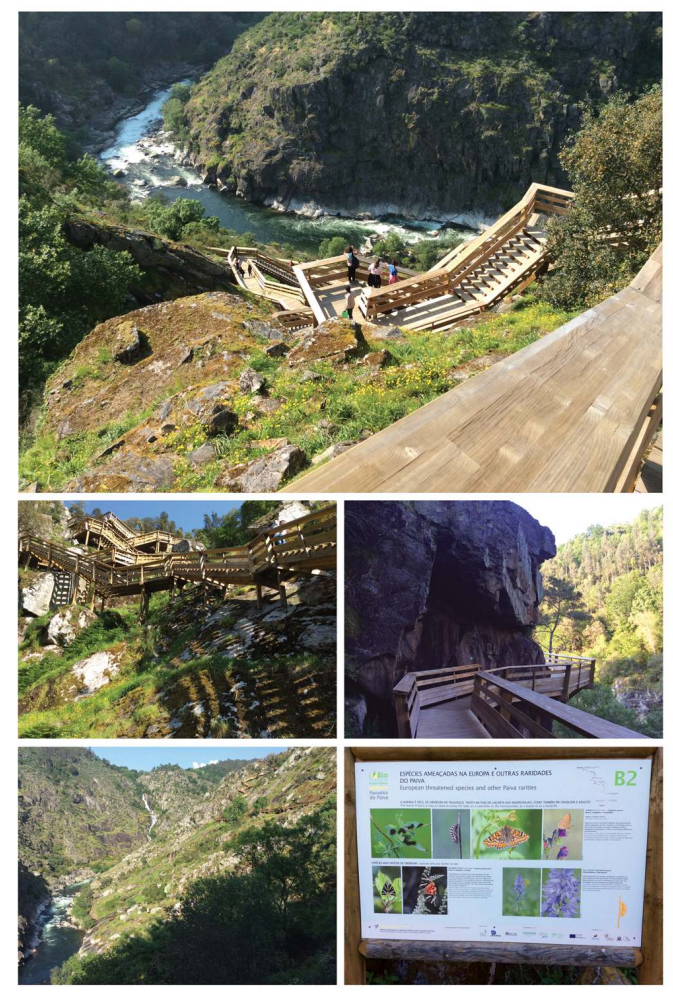

The Passadiços do Paiva is a continuous structure made of pine wood (pinus pinaster), located on the left bank of the Paiva River and extending for a distance of 8,700 meters. This investment is part of a nature tourism and active tourism development strategy. The Paiva is one of the best rivers in Portugal for enjoying white water activities during the winter, including rafting, canoe-raft, hydrospeeding, kayaking, and canyoning (MOREIRA and SANTOS, 2010; MOREIRA, 2012). Top and center: details of the Passadiços do Paiva. Below left: the Aguieiras waterfall, on the right bank, benefits from the natural fracturing of the Alvarenga granite and is good for canyoning. Below right: detail of the interpretive board with threatened European species and other Paiva rarities.

PHOTOS BY CLAUDETE OLIVEIRA MOREIRA, MAY 2016. 
Fig. 2 - Arouca UNESCO Global Geopark
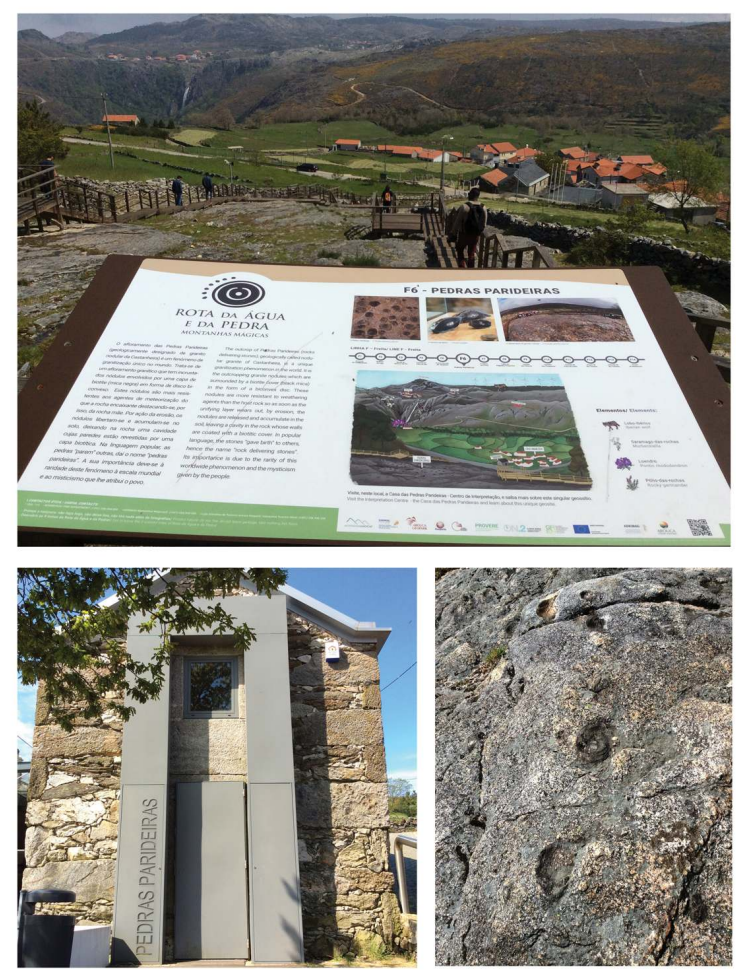

Top: Serra da Freita plateau, Castanheira village, interpretive board on the Rota da Pedra e da Água (Stone and Water Trail), on the main outcrop of Pedras Parideiras ('breeding stones', stones that 'gave birth' to others). Below left: Pedras Parideiras House, Interpretive Center, in Castanheira village, opened to the public in November 2012. Below right: Close-up of the main outcrop of Pedras Parideiras in Castanheira village shows the cavities in the rock whose walls are coated with a biotitic cover, the nodular granite formation of Castanheira is believed to be the only granitization phenomenon of this kind in the world.

Photos by Claudete Oliveira Moreira, May 2016.

According to the World Economic Forum, in 2016 Portugal was the 14th most competitive tourist destination of 136 countries (WEF, 2017). In Portugal that year the number of international tourist arrivals was around 11,423,000 (UNWTO, 2017). This made it the first year in which their number exceeded the number of residents, which was estimated at 10,309,573 (INE, 2017a). Tourism is an extremely significant activity for the Portuguese socio-economy. In that year it accounted for about $16.5 \%$ of the country's total exports, while the figure for 2017 was 17.8\% (Bank of Portugal [BP], 2018), with travel and tourism representing the largest share in Portugal's total exports of goods and services. Tourism contributes a lot to the internationalization of the Portuguese economy. In 2016 it accounted for $6.4 \%$ of gross domestic product (GDP), with direct employment in tourism being about $8.1 \%$ of total employment. It is worth noting that in the European Union in 2016 tourism accounted for $3.7 \%$ of GDP, with jobs in tourism amounting to $3.6 \%$ of total employment. If we consider not only the direct contributions but the indirect and induced inputs, too, the travel and tourism segment represented $16.6 \%$ of the national GDP and $19.6 \%$ of the total employment in Portugal in 2016. The equivalent figures for the European Union were $10.2 \%$ and $11.6 \%$, respectively (WTTC, 2017). The strategic relevance of tourism in Portugal is thus apparent not only by enhancing the value of the country's heritage and territory, but also by promoting regional planning, receiving investment, 
generating wealth, creating employment and boosting Portugal's image abroad. In the last 50 years tourism has contributed significantly to driving Portugal's economic growth and development, inducing a social restructuring and a cultural transformation within the country, making it increasingly cosmopolitan.

The purpose of this article is to explain how tourism in Portugal has evolved in the last 50 years. It describes the growth in tourism demand and the internationalization of the destination and argues that this growth has benefited from: the investment in air and maritime infrastructure; the organization of international events, particularly from the fact that some Portuguese cities have been European capitals of culture; from the heightened commitment to promotional campaigns, both at home and abroad; the inscription of assets on UNESCO's World Heritage List; the surge in tourism in rural areas; the structuring of tourist products like golf, nautical tourism, gastronomy and wine, nature tourism and other categories; the revitalization of health and wellness as tourist products; and, medium and long-term tourism planning.

6 In terms of methodology, various sources have been cross-referenced to retrace the evolution of tourism in Portugal in the past 50 years. The campaigns promoting the destination at home and abroad were sequenced chronologically and planning instruments were consulted. The data collection presented was compiled with the aid of official statistics and also benefited from specific information requested from organizations like the ICCA (International Congress and Convention Association) and from the author's own data collection. There was an interest in mapping the various indicators so as to grasp the pattern of distribution in the national territory of the tourist supply and demand as it stands today, and therefore the golf courses, marinas and yachting harbors have been georeferenced. The Tourism Uptake Rate (TUR) in Portuguese municipalities was also calculated. These procedures and the conclusions they lead to bear out the contribution of this article to the understanding of tourism in Portugal.

\section{2 - The Growth of Tourist Demand and the Internationalization of Portugal}

7 The number of overnight stays in Portugal has been progressively rising (Fig. 3). In the 1960s the expansion of commercial air travel helped to increase the number of tourists and to internationalize tourist demand in Portugal, a demand coming substantially from the United Kingdom and the USA (Table 1), which targeted luxury, 1st and 2nd class hotel establishments, because of the poor quality of 3rd class hotels and boarding houses. In terms of destinations, this demand showed a particular interest in Lisbon and its environs, as well as the Algarve beaches and the seaside resorts which punctuate the western Portuguese coast, where there was a greater supply of accommodation (CAVACO , 1979). Resorts like Figueira da Foz saw a significant demand from Spanish visitors. In the 1960s the accommodation capacity tripled, and simultaneously the supply expanded and cheaper facilities began to appear, such as camping and caravan sites, and youth hostels.

In 1973 the combination of the oil crisis and the devaluation of the dollar caused a downturn in tourism, particularly inbound tourism. In the mid-1970s, the years that followed the revolution which established democracy in Portugal (April 25, 1974) saw a fall in tourist demand. In 1975, but more especially in 1976 and 1977, there was a pronounced rise in the number of overnight stays in hotel establishments, which was due 
to the State having to ensure accommodation for the many thousands of people returning from the former colonies (Angola, Cape Verde, Guinea-Bissau, Mozambique, and São Tomé and Príncipe). This fall-back solution shows that tourist accommodation was politically exploited since there was no rise in the number of existing hotel establishments. At the end of February 1977 the Portuguese escudo was devalued, which motivated tourist visitors from Germany, the United Kingdom, the Netherlands, Sweden and the United States of America. In the wake of Portugal joining the European Economic Community in 1986, the investment in road infrastructure led to the improvement of internal accessibility and facilitated the journeys of foreign tourists.

Fig. 3 - Number of hotel establishments and number of overnight stays in Portugal, 1965-2016

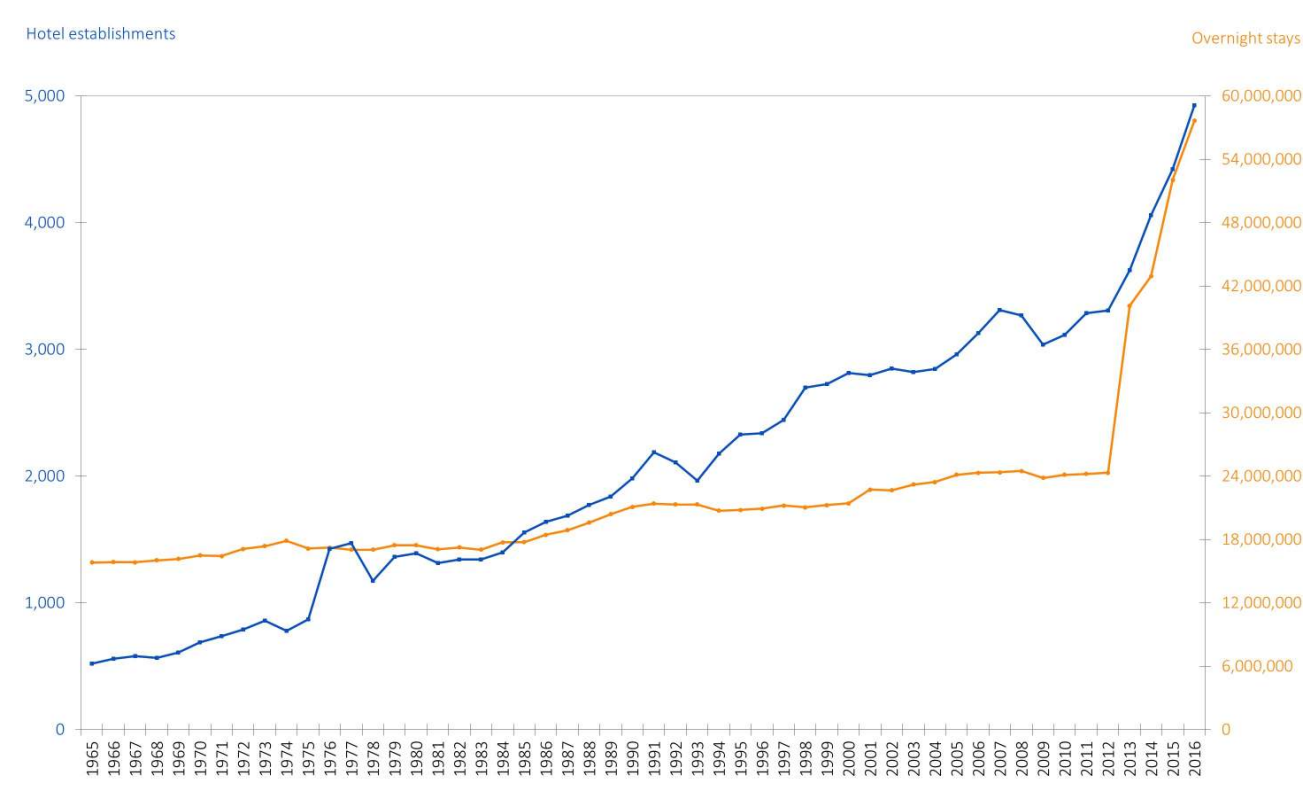

$\rightarrow$ Number of overnight stays in hotel establishments in Portugal $\rightarrow$ Number of hotel establishments in Portugal

Source: Instituto Nacional de Estatística, Lisbon.

The last fifty years have seen appreciable changes in tourist demand in Portugal. Whereas 50 years ago overnight stays by the Portuguese accounted for over half of all overnight stays, this significance has decreased (table 1). Domestic tourism declined. It was only in the III Plano de Fomento (3rd Development Plan) (1968/1973) that domestic tourism was valued from an economic standpoint. The IV Plano de Fomento (4th Development Plan) (1974/1979) aims at the democratization of domestic tourism, extending it to embrace more social classes. The decrease in domestic tourism is more pronounced in the 1980s, continuing in the 1990s. After joining the EEC in 1986, the Portuguese started to enjoy greater purchasing power and easier access to credit, and so they began traveling more and picking international tourist destinations.

10 At the same time, Portugal became internationalized as a destination, which increased the demand for seaside resorts. Currently in Portugal the main origins of international tourist demand are European: the United Kingdom, Germany, Spain, France and the Netherlands. Outside Europe, Brazil and the United States of America are major sources of tourists. In the context of Portugal's strategic management there has been an effort to diversify the origin of tourists to prevent an excessive dependence on the regular 
countries of origin, which made the Portugal destination vulnerable. As J. ANDRAZ and P. RODRIGUES (2016) noted, tourism flows from Germany, the Netherlands and United Kingdom show high sensitivity to economic cycles and are tending to decline. J. SERRA, A. CORREIA and P. RODRIGUES (2014) found that six of the major international tourism source markets are European. They concluded that they have been decreasing since 2000, although this tendency is not homogeneous at the regional level, based on seven tourism regions (Alentejo, Algarve, Azores, Centre, Lisbon, North and Madeira). More recently Portugal has been promoted as a tourist a destination not only in Brazil and the United States of America, but also in Russia, China, and in Scandinavian countries. In Scandinavia the focus has been more specific on golf and nautical tourism, which are strategic products since they even out the seasonal tourist demand, which in Portugal has been based on the sea and the sun for decades.

Table 1 - Percentage of overnight stays in Portugal by place of residence, 1965-2016

\begin{tabular}{|c|c|c|c|c|c|c|c|c|c|}
\hline Period & Portugal & $\begin{array}{l}\text { United } \\
\text { Kingdom }\end{array}$ & Germany & Spain & France & Netherlands & Brazil & USA & Total \\
\hline $1965-1970$ & 52.2 & 10.4 & 5.1 & 3.8 & 5.8 & 1.3 & 1.7 & 9.7 & 90.0 \\
\hline $1971-1980$ & 55.0 & 10.5 & 7.6 & $1.0^{(a)}$ & 3.0 & $0.5^{\text {(a) }}$ & 1.0 & 4.8 & 83.4 \\
\hline $1981-1990$ & 32.4 & 24.0 & 8.9 & 2.7 & 3.5 & $3.3^{(b)}$ & 0.9 & 3.2 & 78.9 \\
\hline $1991-2000$ & 28.7 & 21.2 & 15.5 & 5.9 & 3.2 & 5.4 & $0.8^{(c)}$ & 2.0 & 82.7 \\
\hline $2001-2010$ & $33.0^{(\mathrm{d})}$ & $19.3^{(\mathrm{d})}$ & $10.6^{(d)}$ & $7.6^{(\mathrm{d})}$ & $3.6^{(d)}$ & $4.9^{(d)}$ & $1.2^{(\mathrm{d})(\mathrm{e})}$ & $1.7^{(\mathrm{d})}$ & $81.9^{(\mathrm{d})}$ \\
\hline $2011-2016$ & $30.8^{(f)}$ & $16.1^{(f)}$ & $9.5^{(f)}$ & $7.7^{(6)}$ & $6.4^{\left({ }^{()}\right.}$ & $4.8^{(f)}$ & $2.8^{(f)}$ & $1.9^{(n)}$ & $80.0^{(f)}$ \\
\hline $1965-2016$ & 34.3 & 18.5 & 10.7 & 5.7 & 4.1 & 4.2 & 1.4 & 2.6 & 81.5 \\
\hline
\end{tabular}

(a) 1976, 1977, 1978, 1979 and 1980, no data; (b) 1981, 1982, 1984 and 1985, no data; (c)1994 and 1995, no data; ${ }^{(d)} 2002$ series break; (e)2003 and 2004, no data; ( ${ }^{(f)} 2013$ series break

Source: Instituto Nacional de Estatística, Lisbon.

\section{1 - The Importance of Air Transport}

11 The creation of the national airline (TAP) in 1945 along with the building of international airports contributed to the growth of tourist demand and to the internationalization of Portugal as a destination. Portugal now has 14 airports (fig. 4) and a series of aerodromes geared to regional traffic. Of these, Lisbon airport deserves a special mention. It was the first to be built in mainland Portugal and opened to traffic in 1942; it handles the most traffic, catering for nearly $50 \%$ of the total passengers (49.7\%) (INE, 2017b). This was followed by airports in Porto in 1945, Porto Santo in 1960, Madeira in 1964 and Faro in 1965, and their development played a huge part both in the internationalization of tourist demand and in the growth and consolidation of tourist destinations. Faro airport is especially focused on non-regular international flights. In the Azores, the construction of airports and aerodromes began in 1930 with Lages international airport on Terceira Island. In 1945, Santa Maria airport was inaugurated and 1969 saw the inauguration of Ponta Delgada international airport on the island of São Miguel. Horta airport, on the island of Faial came in 1971, followed in 1972 by the airport on Flores, in 1981 by one on Graciosa, in 1982 by one on Pico and in 1983 by airports on the islands of São Jorge and Corvo.

In Portugal, commercial traffic in 2016 reached 188,480 aircraft landed and exceeded 45 million passengers $(45,236,904)$ (INE, 2017b). In terms of the total number of international passengers landed, Lisbon airport $(9,730,168)$ handled the most, followed by Porto $(3,804,099)$, Faro $(3,604,726)$ and Funchal $(865,862)$. 
Fig. 4 - Total number of international passengers landed at Portuguese airports in 2016

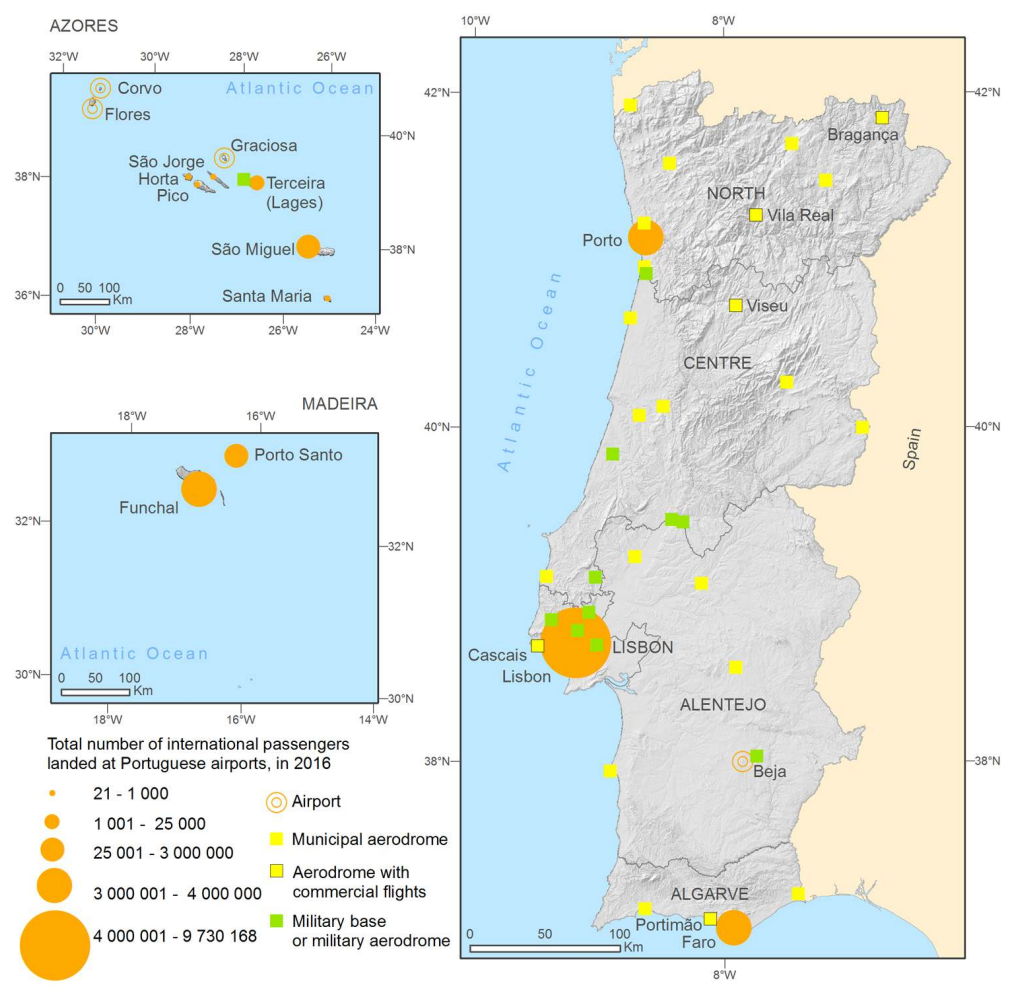

Source: Data from Instituto Nacional de Estatística, Lisbon, map by Claudete Oliveira Moreira

The coming of low-cost airlines had an immediate effect on the rise of the number of tourists in Portugal. Faro was the first national airport to benefit from low-cost airlines, in 1996 (it is worth noting that the terminus of air transport liberalization in Europe happened in 1997, to the then 15 Member-States, with the process having started in 1987). In Madeira, the entry into service of EasyJet in 2007 translated into a significant rise in the number of passengers disembarking. In Porto, low-cost air transport began in 2004, with Air Berlin. In the Azores, low-cost airlines began operating in March 2015. The Open Skies Agreement between the European Union and the United States of America in 2007, revised in 2010, meant a complete opening of transatlantic routes to European and American airlines, despite Portugal being one of the Member-States that already had a bilateral agreement with the USA for this.

\section{2 - Event Planning and the Internationalization of Portugal}

The planning of international events contributed significantly to the growth of tourist demand and to the internationalization of Portugal. Some of these events encouraged a decentralization of tourist demand within the national territory since they took place in medium-sized cities.

In Portugal the planning of big international events started with TAP's Portugal Rally (a rally sponsored by TAP, whose first edition was in 1967) becoming one of the World Championship rallies, which happened in 1973. The event was considered the World's Best Rally five times. When it comes to sporting events, the planning of the European Football Championship, Euro 2004 is worth noting. This event had a decentralized 
implementation, which made it possible to heighten the profile of some medium-sized Portuguese cities where 10 football stadiums were built or rehabilitated, such as Leiria, Coimbra, Braga and Faro. This edition of the event was considered by UEFA to be one of the best planned ever. One million tourists and 10,000 journalists attended the various matches. The effect of some of these events has been recognized by F. ALMEIDA GARCIA (2014). Another important sporting event is the Volvo Ocean Race, which is the biggest worldwide sailing event. Lisbon has been a stopover port since the 2011-2012 race. In 2017-2018 the boatyard, the technical base, will be in Lisbon in Doca de Pedrouços, where it will probably remain for the next 10 years. It has already had a huge economic impact on the city.

In terms of cultural events in the 1970s we have the International Cascais Jazz Fest. The 1st edition was in 1971 with over 10,000 people attending the first night, and it continued until 1988. A highly relevant cultural initiative for urban regeneration, one that strengthens the identity and promotes the culture and the image of a city, giving it international exposure, and, ultimately, improving tourism, is the European Cultural Capital scheme. So far Portugal had three European Cultural Capitals: Lisbon in 1994, Porto in 2001 and Guimarães in 2011. But the biggest cultural event to take place in Portugal was the World Trade Fair in Lisbon, Expo'98. The importance of big universal exhibitions for tourist destinations is highlighted by J.-B. CASTET (2008; 2010). Expo'98 was based on the theme Oceans, a heritage for our future, which celebrated the 500th anniversary of the discovery of the sea route to India by Vasco da Gama. It involved a major urban regeneration project on the right bank of the River Tejo to expand the city to the east. This event had over 11 million visitors between May and September 1998.

Regarding big event planning, international associative events are worth mentioning. This market covers a wide range of types and categories of meetings like medical meetings (the largest segment), scientific, other academic events, professional bodies, social groupings and trade organizations. These events were not at all relevant in Portugal in the 1960s and 1970s, but they began to gain ground in the 1980s. The Bolsa de Turismo de Lisboa, BTL (Lisbon International Tourism Fair) brings the largest number of the tourism system's stakeholders to Portugal, had its first edition at the end of the decade, in 1989 (fig. 5). These events grew substantially from the end of the 1990s and beginning of the 21st century. The staging of Lisbon's World Trade Fair, Expo'98, induced a rise in organized events in Portugal (fig. 6). 
Fig. 5 - The Lisbon International Tourism Fair, BTL, at International Fair of Lisbon, FIL, Parque das Nações, celebrates its 30th anniversary in 2018
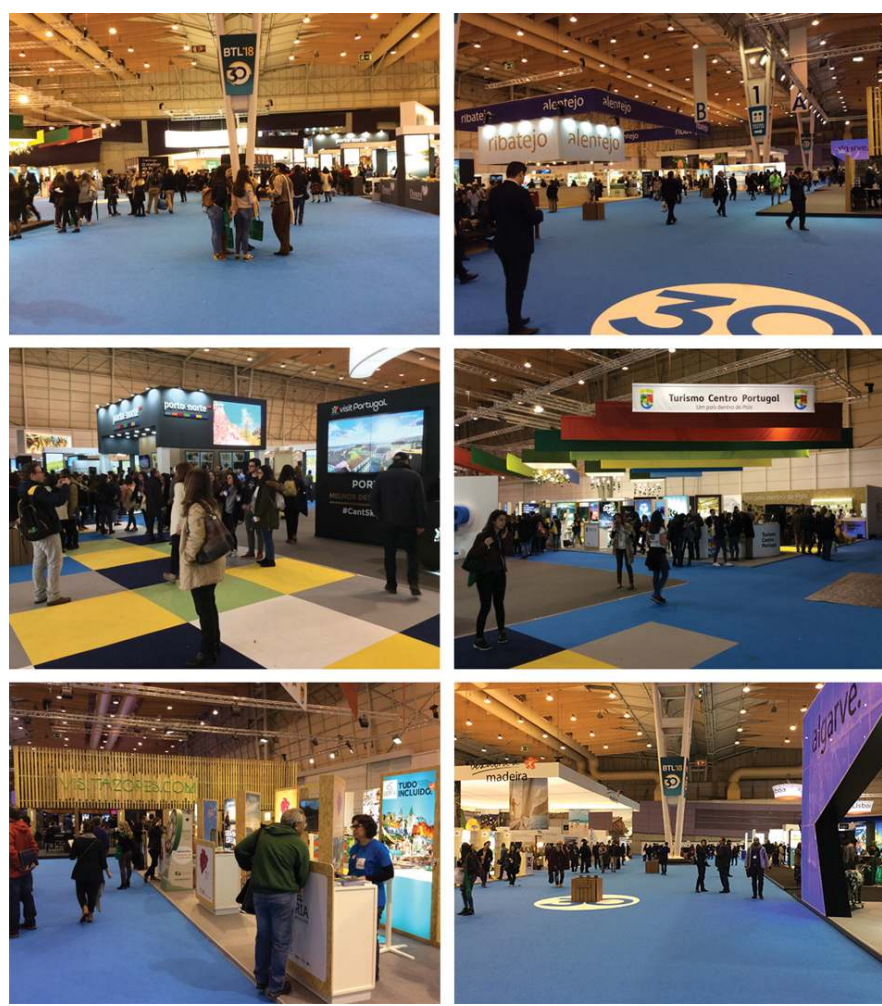

Portuguese Regional Tourism Authorities had stands promoting their regions: Alentejo, North, Centre, Azores, Madeira, Lisbon, and Algarve.

PHOTOS BY CLAUDETE OLIVEIRA MOREIRA, MARCH 2018.

Until the 1990s Portugal only had a small number of suitable venues and staged a correspondingly small number of sporting, cultural, and trade events. Over the years a number of facilities have been built to accommodate big events: the Feira das Indústrias (1952-1957), Junqueira, Belém-where the Feira Internacional de Lisboa, FIL was until 1999, when it was relocated in the Parque das Naçôes-today Lisbon's Congress Centre; the EXPONOR-Feira Internacional do Porto, Matosinhos (1987), currently the largest exhibition park in Portugal; ExpoSalão, Batalha (1992), the largest private exhibition center in Iberia; the Centro Cultural de Belém (1992); Europarque, Santa Maria da Feira (1995); the Altice Arena, Lisbon (former Pavilhão Atlântico, in Parque das Nações, 1998), in a highly versatile precinct which accommodates various types of events; the Serralves Museum of Contemporary Art, Porto (1999); the Multiusos de Guimarães, Multipurpose Hall (2001); Casa da Música, Porto (2005); Convention Center and Cultural Space of Convento São Francisco, Coimbra (2015).

The investment made in facilities in Portugal in the 1990s for hosting events enabled more events to be held in the following decades. In 2016, Portugal was in 10th place worldwide, having hosted 287 major events. That same year Lisbon ranked 9th worldwide for the number of meetings per city, with 138 international events, while Porto, Portugal's second-largest city, was in 31st place, having held 70 international associative events (ICCA, 2017). Portugal's management strategy is more and more about attracting the largest possible number of international events. Note that Lisbon provided the venue for the Web Summit, one of the largest tech conferences in the world, for the first time in 
November 2016, and managed to secure the event for the next two years. According to the organizers the event was attended by more than 53,056 participants from 166 countries and is estimated to have had a direct economic impact of 200 million euros. The planning of these international events has been extremely significant for the country's image and for promoting Portugal.

Fig. 6 - Number of international association meetings in Portugal, from 1965 to 2016

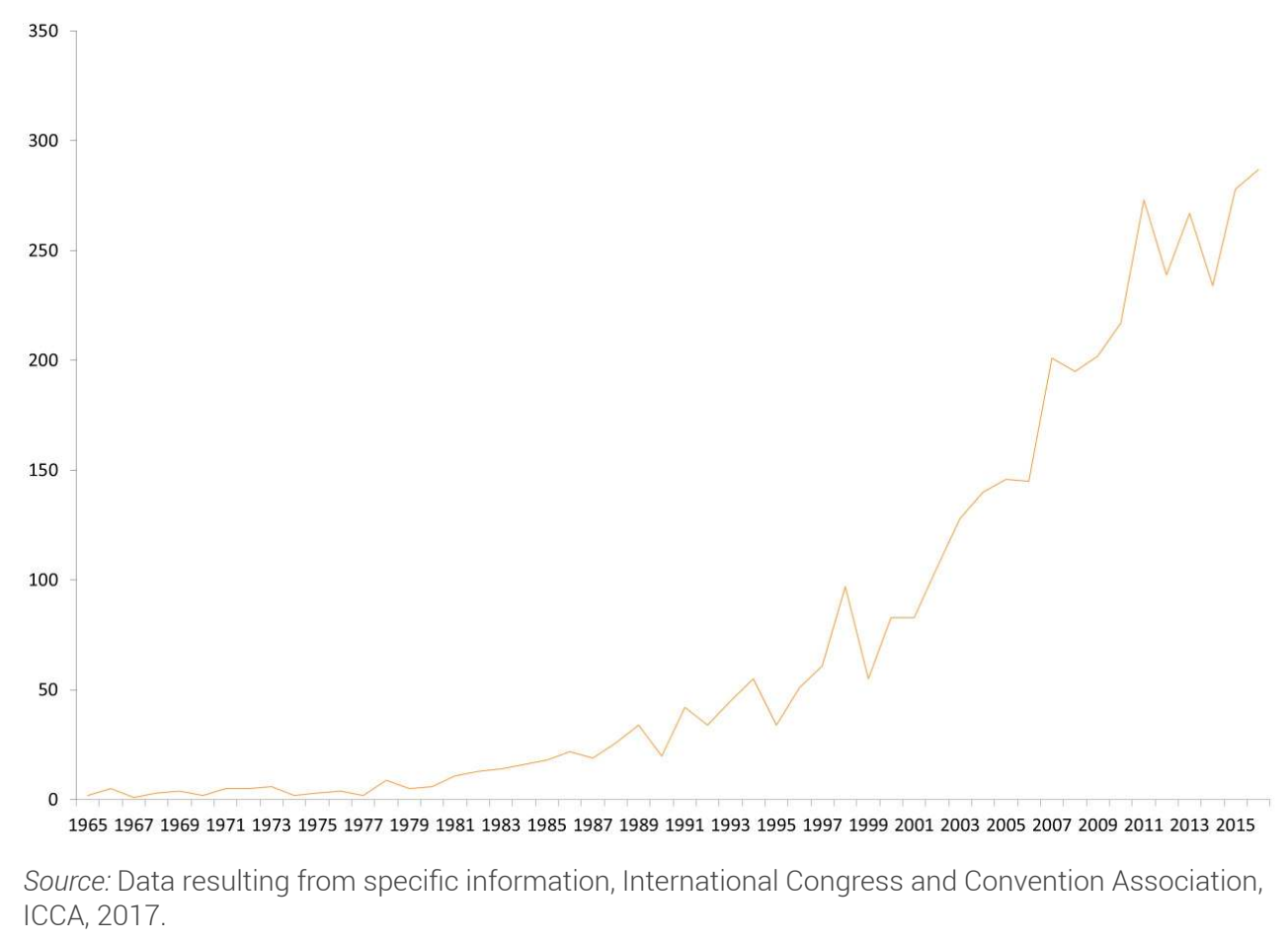

\section{3 - Promoting Portugal}

The brand of a tourist destination, its image, its identity, its values, its reputation, are today essential for attracting tourists, and the quality of the tourist experience is truly relevant to the brand. As important as branding a destination is the management and promotion of the brand. In Portugal there has been a significant investment in external and internal promotional campaigns (for more information on these campaigns, see PINA , 1988; DOMINGUES, 2000; LOPES and GAMBOA, 2001; PCM, 2011; MANGORRINHA, 2012; DIONÍSIO, 2012; RAMALHO, 2013; COSTA and VIEIRA, 2014).

In the 1970s, the first external promotional campaign after the fall of the fascist dictatorship (April 25, 1974) took place in London, with the slogan Portugal feel free (1974), as a wide allusion to the freedom the destination was offering. In this decade, too, the Direção Geral do Turismo (DGT) (Portuguese Tourism Board) developed a marketing campaign abroad based on a modern image of Portugal Going to Portugal (1976). In 1986 the Instituto de Promoção Turística (IPT) (Institute for the Promotion of Tourism) was created. In 1992 the Instituto das Empresas para os Mercados Externos (ICEP) (Institute for Foreign Trade) invested in this promotion, and the artist José de Guimarães created the graphic identity, which is still used today for the tourist promotion of Portugal. Portugal's tourist promotional campaigns abroad have been continuous since 1994. While the 1990 s were marked by two campaigns Portugal the thrill of discovery (1994-1998) and Portugal the 
choice (1999) drew attention to the quality of the products, the focus in the first 15 years of the 21st century was the differentiation of Portugal. There were repositioning campaigns and tactical campaigns, an example of the latter being the one before Euro 2004 with the slogan Take a break (2003), which promoted Portugal as a safe destination, so that in 2004, the year of the European Football Championship, the campaign The extratime is always the best part of the game could be launched. Experiences are increasingly valued, as exemplified by the campaign Portugal. Deeper experience (2006). In the context of the repositioning of Portugal, the campaign Europe's West Coast (2007-2009), launched at the time of the Treaty of Lisbon, sets the country apart from the Mediterranean, the south of Europe, and presents it as an Atlantic destination. The Atlantic is of great historical importance for Portuguese society and for the national economy in the context of the European Union within the blue growth strategy. The Atlantic is a constant factor in the Portuguese tourist offer: cruise tourism, nautical sports and leisure, thalassotherapy, extensive beaches or small ones that emerge in small rocky coves, landscape touring, cycling and walking, birdwatching, surfing and wave sports, whale watching, diving, sport fishing and gastronomy, in which fresh fish and shellfish play a major part.

22 In 2013 there was a change in Portugal's international promotional campaigns, they stopped being institutional and started being digital. That year's campaign used exclusively digital media: Google (Google AdWords and Google Display), YouTube, and Facebook, as well as specific websites for certain markets. The website www.visitportugal.com, launched in 2004, was of great significance for this campaign. It enhanced the visibility of the destination, and made it possible to reduce the cost.

In May 2017 a wholly digital campaign was launched by Turismo de Portugal in about 20 source countries (Spain, France, United Kingdom, Ireland, Norway, Sweden, Denmark, Finland, Netherlands, Belgian, Italy, Russia, United States of America, Canada, Brazil, India, and China), a campaign aimed at international tourists with the tagline, 'Can't Skip Portugal.' Running in 2017 and 2018 the campaign has four films about Portugal that show some lesser-known aspects of the destination. The films were shot in December, in the winter. Portugal is aiming to assert itself not as a summer destination but as a yearround destination. Three of them are short films targeting three different segments. One features Jack, an entrepreneur who decides to take a relaxing break in contact with nature ('Can't Skip Freedom'), another shows us Chloe, a young French student who is seeking inspiration in a city ('Can't Skip Inspiration'), and the third is about Klaus, a German in his sixties who wants a change of life, a fresh start, living in the Portuguese countryside ('Can't Skip New Beginnings'). The fourth film brings these three characters together ('Can't Skip Us. Can't Skip Portugal').

The messages they convey are designed to promote the experiences and appeal to the emotions. 'Can't skip... love, joy, smiles, life, opportunities, hope, new beginnings, challenges, and happiness.' The campaign is based at a website (http:// www.cantskipportugal.com/en) which lets visitors choose the destination according to how they feel, and presents itself as an emotion travel guide.

The external promotional campaigns always favored central and western European markets (France, United Kingdom, Germany, Netherlands and Ireland), southern European markets (Spain and Italy), eastern European markets (Poland and Russia), and also Nordic countries (Denmark, Sweden and Finland). Outside Europe, the target markets 
were the United States and Brazil, with the latter, along with Spain, very occasionally having specific campaigns.

In terms of promoting domestic tourism over the decades, various campaigns were devised to reverse the decline of this demand, which is clear in table 1. In 1969, the Secretaria de Estado da Informação e Turismo (Secretary of State for Information and Tourism) promoted a campaign with the slogan Há sempre um Portugal desconhecido (There is always an unknown Portugal), with various versions adapted to the different regions. Subsequent campaigns kept appealing to the exploration of the country: Descubra um Portugal desconhecido (Discover an unknown Portugal) (1973); Um mundo para descobrir (A world to discover) (2005) and Portugal, um mundo para descobrir (Portugal, a world to discover) (2006), a slogan which is a continuation of the previous campaign; Descubra um Portugal maior (Discover a greater Portugal) (2009); Descubra Portugal: um país que vale por mil (Discover Portugal: a country worth a thousand) (2010), followed by Escolha Portugal: um país que vale por mil (Choose Portugal, a country worth a thousand) (2011). One of the slogans with the most impact was Vá para fora cá dentro (Go outside inside) (1993-1997). This was followed by another campaign that directly encouraged short breaks, contributing to evening out the seasonality of the demand Escapadinha de 3 dias, a melhor forma de fugir à rotina (3 days mini-break, the best way to escape your routine) (1998-2000) and Escolha Portugal (Choose Portugal) (2002).

Investment in new technology becomes evident in the first years of the 21st century, along with the involvement of key players and stakeholders. In the 2009 campaign Descubra um Portugal maior (Discover a greater Portugal) the Entidades Regionais de Turismo (Regional Tourism Authorities) and private operators were involved. A promotional website to publicize domestic tourism was created: www.descubraportugal.com.pt, to involve hotels, travel agencies and tourist operators, encouraging them to make special offers and other tourist services available on this website. It displayed the scope and diversity of the range of tourist products offered in Portugal, incorporating within the campaign the following facts and figures: 701,681 acres of protected areas, 495 beaches, 21 islands, 40 mountain ranges and 26 mountain peaks, 1,452 villages (some historical), 51 cities to visit, 1,067 theaters and concert halls, 2,031 hotels, 1,025 rural holiday houses, 1,394 places of worship, 29 wine regions, and 123 surfing schools.

In the 2016 campaign, with the slogan Ponha Portugal no mapa (Put Portugal on the map) the Portuguese themselves started being involved, i.e., all the potential tourist clients. People were challenged to make 5 to 20 second videos and upload them in the mobile app Glymt (an app created by a Portuguese start-up company). The goals of this campaign are to encourage the Portuguese to (re)discover the country by having a mini-break in the low season, and to highlight the diversity of national tourist amenities.

\section{3 - Structuring the Offer and the Regional Differentiation of Tourist Activity in Portugal}

Its temperate Mediterranean climate with moderately warm summers and mild winters, plus an extensive, low-lying sandy coastline and long Atlantic beaches have long since made sun and sea tourism an important tourist product for Portugal. In 2016 Portugal had 464 coast beaches and estuary transition beaches, to which were added 115 inland beaches. The quality of the bathing water was rated as excellent in $85.1 \%$ of all 
beaches (APA, 2017). It is in the 1960s that we begin to see the growth of tourist demand based on sun and sea, and its effect on the Portuguese coastline with the transformation of fishing communities such as Figueira da Foz, Espinho, Póvoa de Varzim, and Nazaré. The building of the Salazar Bridge was important in the development of tourism south of the River Tejo, in Tróia and Algarve. It was in the 1960s, too, that the Algarve began to make a name as a tourist destination (SIMÕES and FERREIRA, 2017), defining itself as a priority tourist development region where investment was promoted. 1972 saw the opening of the Quinta do Lago in the Algarve, one of the most luxurious resorts in Europe. A. CORREIA and M. KOZAK (2012) note that the south of Portugal, namely Algarve, has managed to attract prestige seekers. A study entitled Aproveitamento Turístico da Península de Tróia (Tourist Utilisation of the Peninsula of Tróia) (1963-1964) was published in 1964. In 1970 the Plano de Ocupação Turística da Península de Tróia (Tourist Occupation Plan for the Peninsula of Tróia) appeared which, contrary to earlier plans, proposes a large, isolated, and concentrated site, with sports facilities, restaurants, nightlife, a museum and conference center. J. ALMEIDA, C. COSTA, and F. SILVA (2017) analyzed the conflict between tourism development, land use planning and natural resource management by examining the tourism vs. territory conflict history on the Tróia-Melides coast since the 1970s.

A strategic product in Portugal, which appears in association with the sun and sea, which helps to level out the seasonality of tourist demand and which contributes substantially to the destination's image, is golf. Portugal is a model destination, in Europe and worldwide, not only for the number of golf courses but also for their high quality, since a lot of them have been designed by renowned architects who have won international awards. Some courses host PGA (Professional Golfers Association) events. About 100 golf courses have been created in Portugal; there were nine in 1965 and 90 more were established between then and 2016. Many of these courses (83\%) appeared in the 1990s and early 2000s (fig. 7). The highest concentrations are in the Algarve, where the first golf course was established in 1966, the Penina Golf Course, and in Lisbon. There are far fewer in central Portugal and Alentejo (fig. 8). It is worth mentioning that the oldest golf course was founded in Porto in 1890 by the English port wine producers who had settled in the city (the Oporto Golf Club). This is well-known because is the oldest golf club in the Iberian Peninsula and one of the oldest in Europe.

Fig. 7 - Number of golf courses created in Portugal from 1965 to 2016 


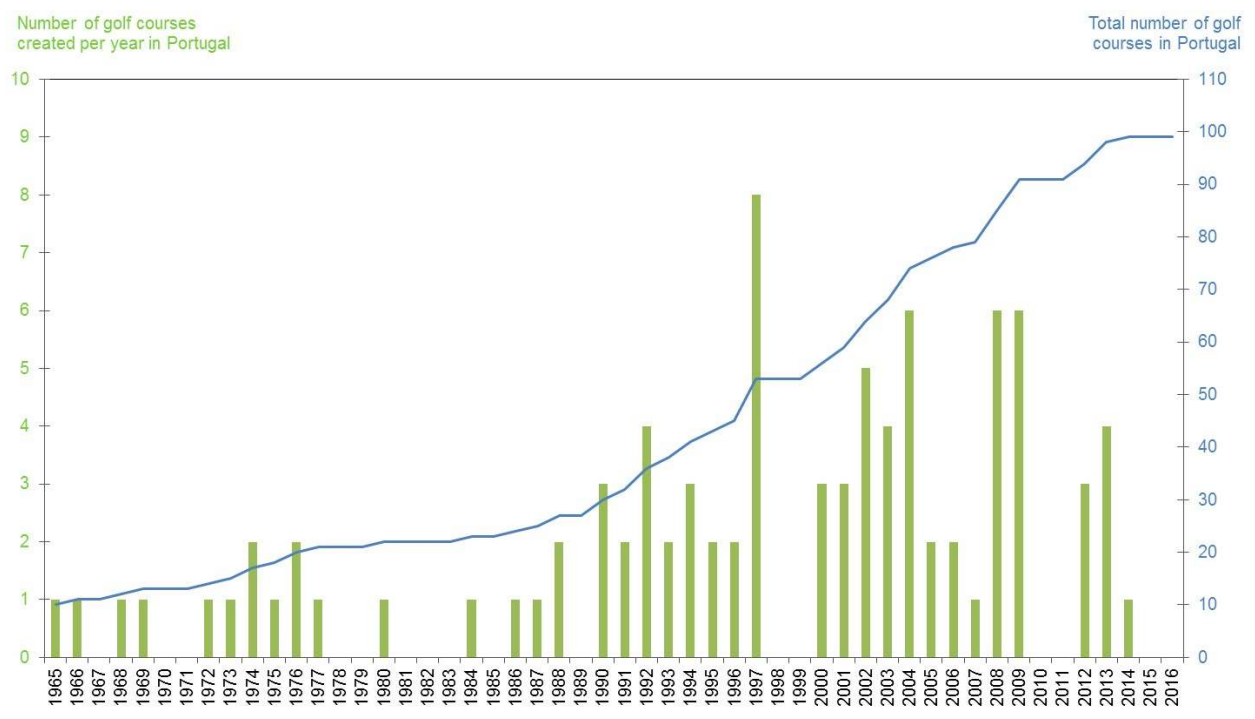

SOURCE: 2017 DATA gATHERED ON EACH gOLF COURSE BY CLAUDETE OLIVEIRA MOREIRA.

Fig. 8 - Distribution of golf courses in Portugal in 2016
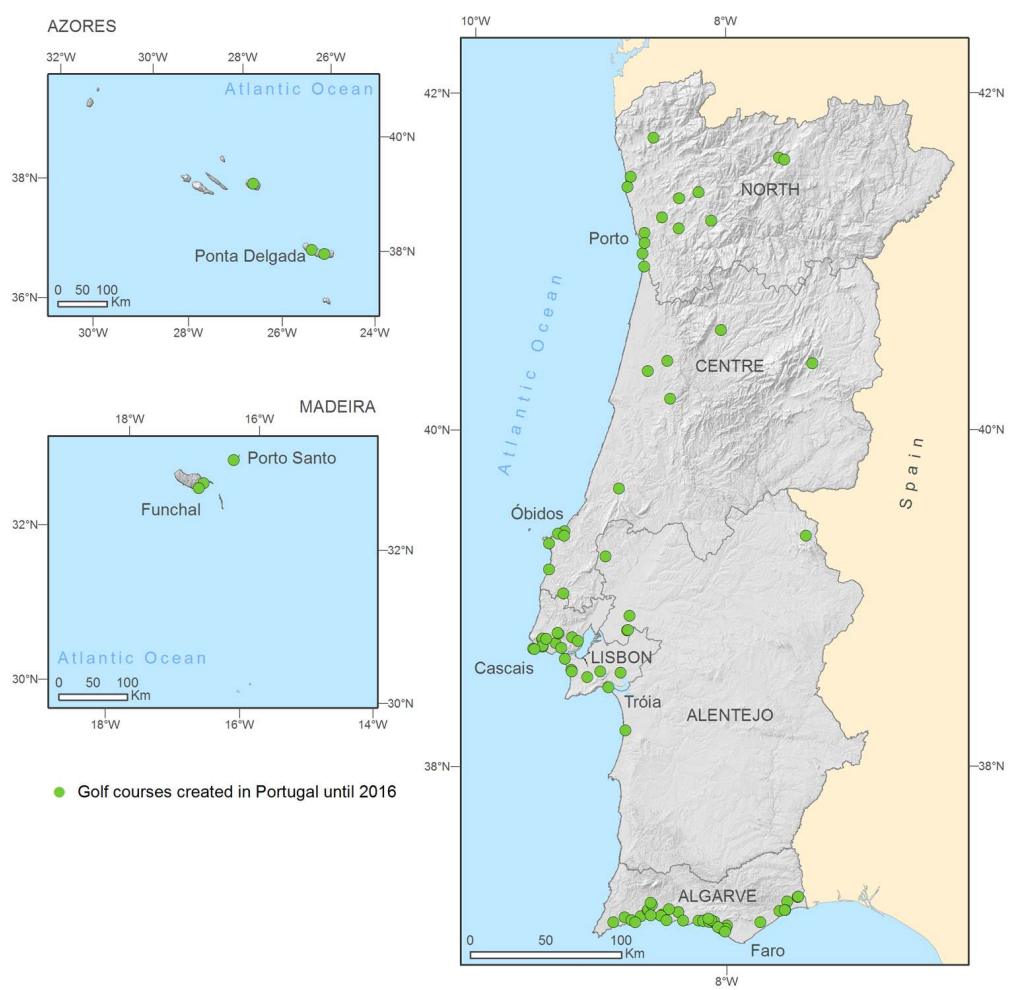

SOURCE: 2017 DATA gATHERED ON EACH gOLF COURSE, MAP BY CLAUDETE OLIVEIRA MOREIRA.

31 A tourist product of great relevance along Portugal's coastline is surfing. This sport has been growing in importance for tourism since 1977, the year of the first national surfing championship in Ericeira. Organizing the surfing world cup in Ericeira in 1990 has led to the worldwide acknowledgement of the quality of Portuguese waves. From then on various destinations in Portugal began to promote themselves for distinctive waves: 
Ericeira for having seven world-class waves; Peniche for having the most tubular wave; Figueira da Foz for having mainland Europe's longest straight wave; Nazaré for having the tallest wave, Praia Norte for having giant waves. Nazaré's waves gained publicity in 2012, when the Hawaiian surfer Garret McNamara surfed the largest wave in the world there, such that the fishing village and seaside resort became a surf destination. Since 2011, Ericeira has been Europe's first World Surfing Reserve and the second one in the world (the first World Surfing Reserve is in Malibu, California, USA). A number of surfing schools have been set up along Portugal's coast (fig. 9). Some of them have been accredited by the Portuguese Federation of Surf and the European Surfing Association and are geared towards wave sports, with several World Surf League events taking place in Portugal. These events have a great economic impact on a local scale. In addition to the occasional events, they organize surf trips, often in Volkswagen vans from the 1950s, 1960s, 1970s, the legendary 'bread loaf' used by surfers, and offer training and courses at various levels of wave sports (surfing, bodyboard, longboard and paddle board). In addition to the schools, there are associations of schools, surf camps, High Performance Surfing Centers. There is a very keen demand throughout the year, in particular from international tourists. The number of international tourists practicing wave sports has increased with the expansion of low-cost airlines operating in Portugal. This benefits especially, but not only, to municipalities close to the main airports and has led to an increase in the provision of accommodation, trade in goods and local services aimed at this tourist demand in many coastal municipalities.

Fig. 9 - Surf schools on the north coast of Portugal
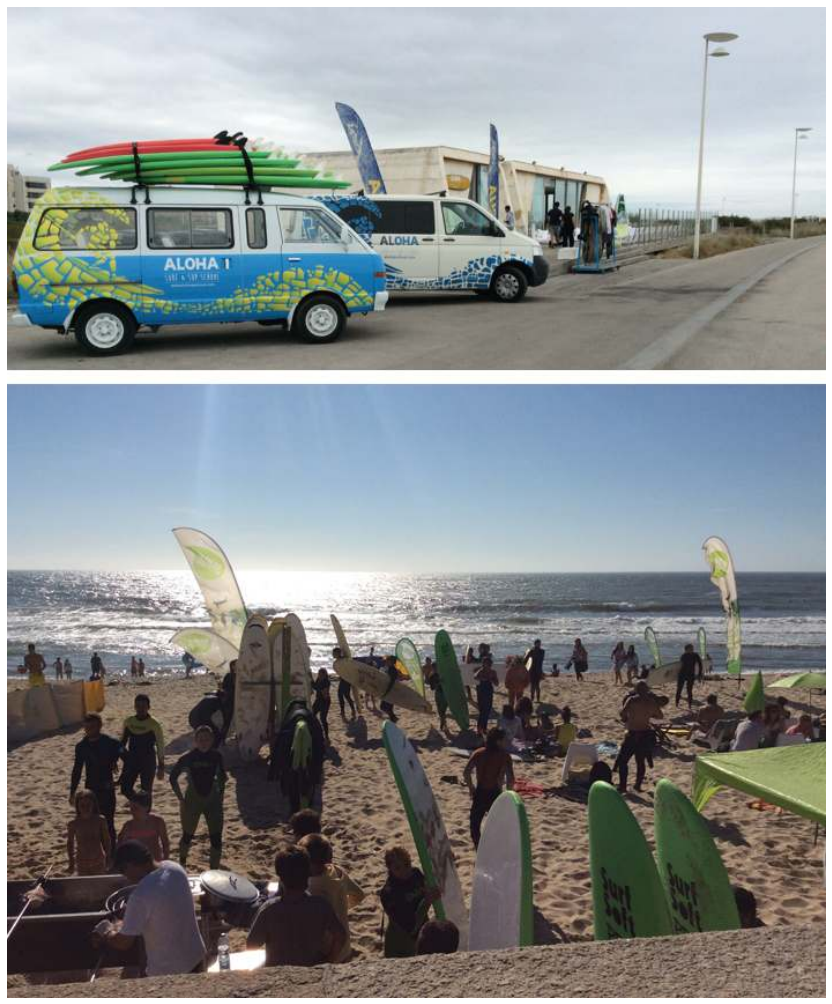

TOP: PRAIA AZUL, VILA DO CONDE MUNICIPALITY, ALOHA SURF SCHOOL, INAUGURATED IN 2002. BOTTOM: ATTITUDE SURF SCHOOL, ESPINHO MUNICIPALITY

PHOTOS BY CLAUDETE OLIVEIRA MOREIRA, OCTOBER 2015 AND JULY 2015, RESPECTIVELY. 
Portugal's position, its long coastline and the existence of seaports all help to heighten its profile as a nautical tourism destination (fig. 10) (FIGUEIRA DE SOUSA, FERNANDES and CARPINTEIRO, 2009; SILVEIRA, 2016) and a cruise tourism destination. Portugal has seen a marked increase in the mooring of cruise ships, and consequently the number of tourists rose as well. Portuguese ports received 439 cruise liners in 2004, a figure which rose to 872 in 2016 (INE, 2005; INE, 2017b). This means there was an average growth rate of $6 \%$ each year. When it comes to cruise ship tourism the three main ports involved are Lisbon, Funchal, and Leixões. These ports are located near the historical centers of their cities and are important to shipping lanes of Europe's Atlantic seaboard, the western Mediterranean, and Atlantic Islands. Thanks to its position in the center of the Atlantic, the port of Funchal has always been of great importance as a trans-ocean port between Europe and America (MOREIRA and FIGUEIREDO, 2017). In Portugal the creation of Gares Marítimas (maritime terminal) in cruise terminals-the port of Funchal international maritime passenger terminal, inaugurated in 2010, the cruise terminal at Leixões, inaugurated in 2015 (fig. 11), and the new cruise terminal at Lisbon (which was inaugurated in 2017)-is strategic. These facilities will help to increase the importance of Portuguese ports when it comes to interporting and turnaround calls, and significant growth in cruise ship tourism is envisaged for Portugal in the coming years.

Fig. 10 - Berths in coastal marinas in Portugal, in 2016
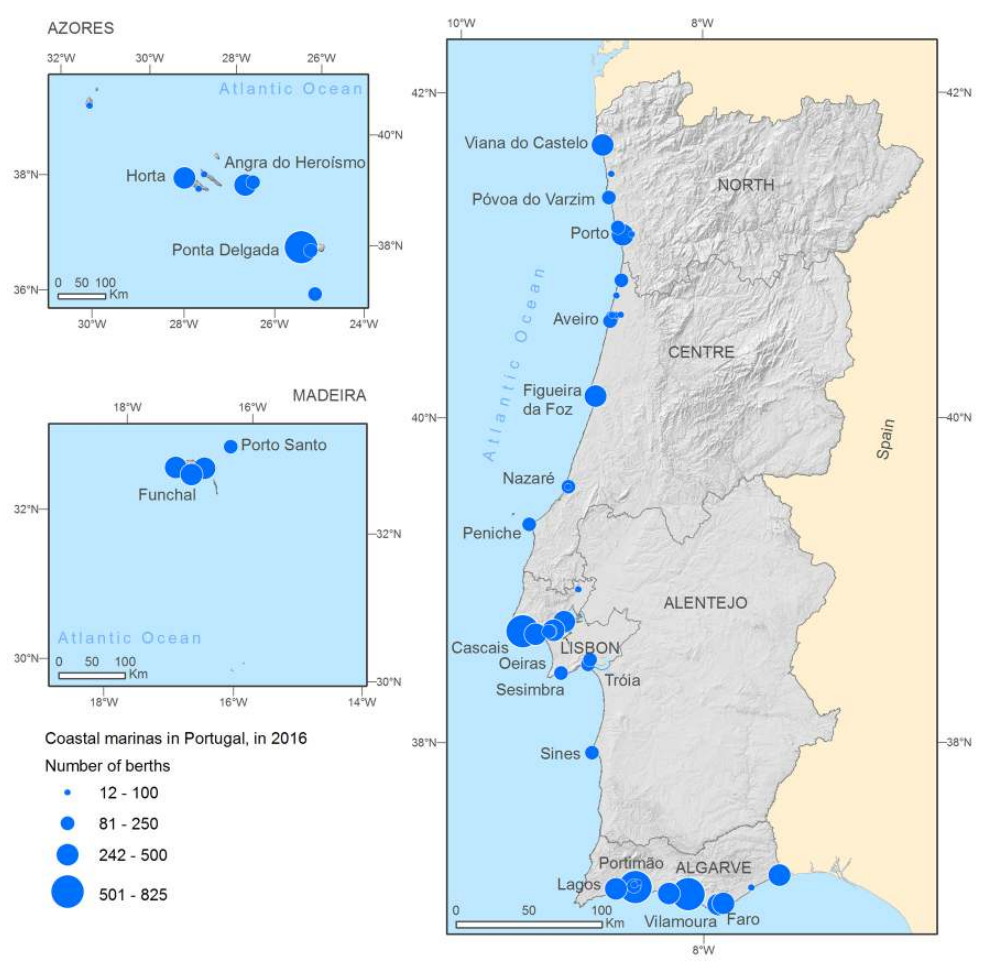

Source: Data sourced from a table in SILVEIRA (2016: 180-185), map by Claudete Oliveira Moreira. 
Fig. 11 - The cruise terminal at Leixões

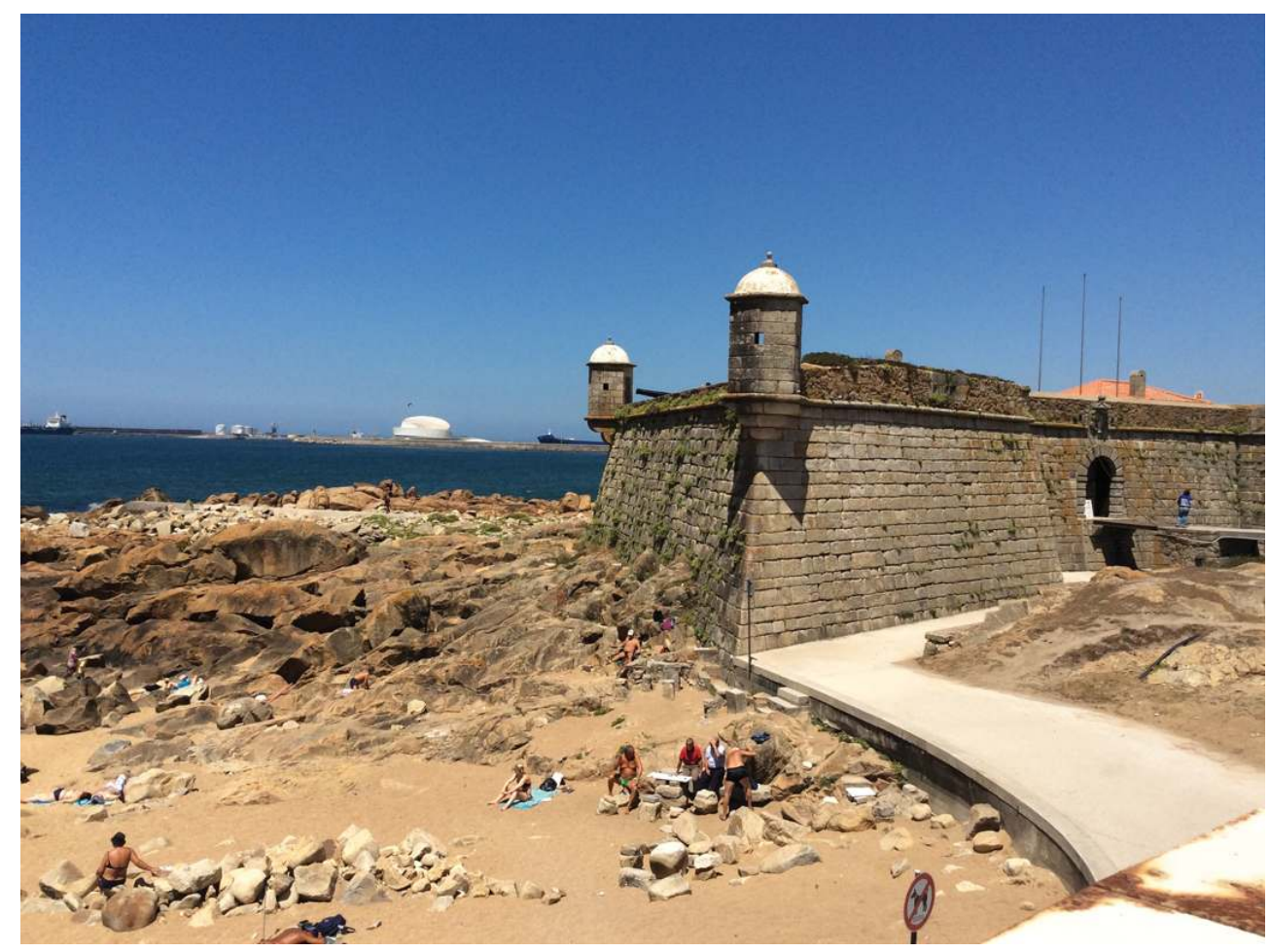

LOCATED AT THE SOUTH MOLE OF THE PORT OF LEIXÕES, 13 KM FROM THE CITY OF PORTO, THE SOUTH QUAY (340 METERS LONg AND -10 METERS DEEP REFERRINg TO THE ZHL LEIXõES HYDROgRAPHIC ZERO) HAS BEEN ABLE TO RECEIVE THE BIggEST LINERS FROM WORLDWIDE CRUISE FLEETS SINCE APRIL 2011, WHICH HAS SIgNIFICANTLY INCREASED CRUISE TOURISM IN THE NORTH OF PORTUGAL. THE WHITE BUILDINg ON THE HORIZON IN THE PHOTO, WHICH LOOKS LIKE AN UNROLLING ROLL OF PAPER, IS THE PASSENgER BUILDINg AT THE LEIXÕES TERMINAL. THE TERMINAL DOES NOT HAVE A CAPACITY LIMIT FOR PASSENGERS IN TRANSIT; THE TURNAROUND CAPACITY LIMIT IS 2,500 PASSENgERS, ACCORDINg TO THE APDL (PORT AUTHORITY OF DOURO, LEIXÕES, AND VIANA DO CASTELO). THE BUILDINg ALSO HOUSES THE SCIENCE AND TECHNOLOgY PARK OF THE SEA OF THE UNIVERSITY OF PORTO, WHICH INCLUDES THE MARITIME RESEARCH CENTRE. THE FORT OF SÃO FRANCISCO DO QUEIJO IS THE BUILDING IN THE FOREgROUND.

PHOTO BY CLAUDETE OLIVEIRA MOREIRA, JULY 2015.

33 As well as sea cruises there has been a growth in river cruises on the main Portuguese rivers including the Rivers Vouga, Guadiana, Sado, Tejo, but fundamentally the River Douro. The creation of reservoirs with the construction of dams and flood gates on the River Douro from 1961 to 1986 made what is one the largest rivers in Portugal navigable. Douro river cruises have become increasingly popular since the 1990s (MOREIRA and SANTOS, 2016). They pass through a landscape of unusual beauty, the Alto Douro Vinhateiro (Upper Douro wine-growing area) (see PINA, 2007), a landscape which characterizes the Douro wine region, the world's oldest regulated wine region, established in 1756. The exceptional universal value of this landscape led to it being added to the UNESCO World Heritage List in 2001. That same year Porto was European Capital of Culture (see CORFU, BREDA and COSTA, 2006), as Guimarães would come to be in 2012. The growth of tourism in Porto and northern Portugal owed a considerable amount both to these facts and to the fact that the historical center of Porto, a city on the right bank of the River Douro near the estuary, was added to UNESCO's representative World Heritage List in 1996. 
It is undeniable that the inscription of sites on the World Heritage List contributed to making the tourist destinations much better known. Portugal has 15 sites around the country on this list (fig. 12 and fig. 13). These inscriptions began in 1983. The latest site to be added is the Universidade de Coimbra, Alta e Sofia (University of Coimbra, Alta and Sofia). The inscription of cultural events on the UNESCO list of the Intangible Cultural Heritage of Humanity has played an important part in enhancing Portugal as a destination. Portugal has five intangible assets on the list: (i) Fado, inscribed in 2011; (ii) the Mediterranean diet, inscribed in 2013; (iii) Cante Alentejano (Alentejo singing), inscribed in 2014, (iv) Portuguese falconry, inscribed in 2016, and (v) Craftmanship of Estremoz clay figures, inscribed in 2017. The manufacture of cowbells was added to the Intangible Cultural Heritage, Urgent Safeguarding List in 2015, with the black pottery form Bisalhães following in 2016. The inscription of sites on the World Heritage List has helped to stimulate national and international tourist demand and its dispersion throughout the national territory.

Fig. 12 - Portuguese sites on the UNESCO World Heritage List in 2018

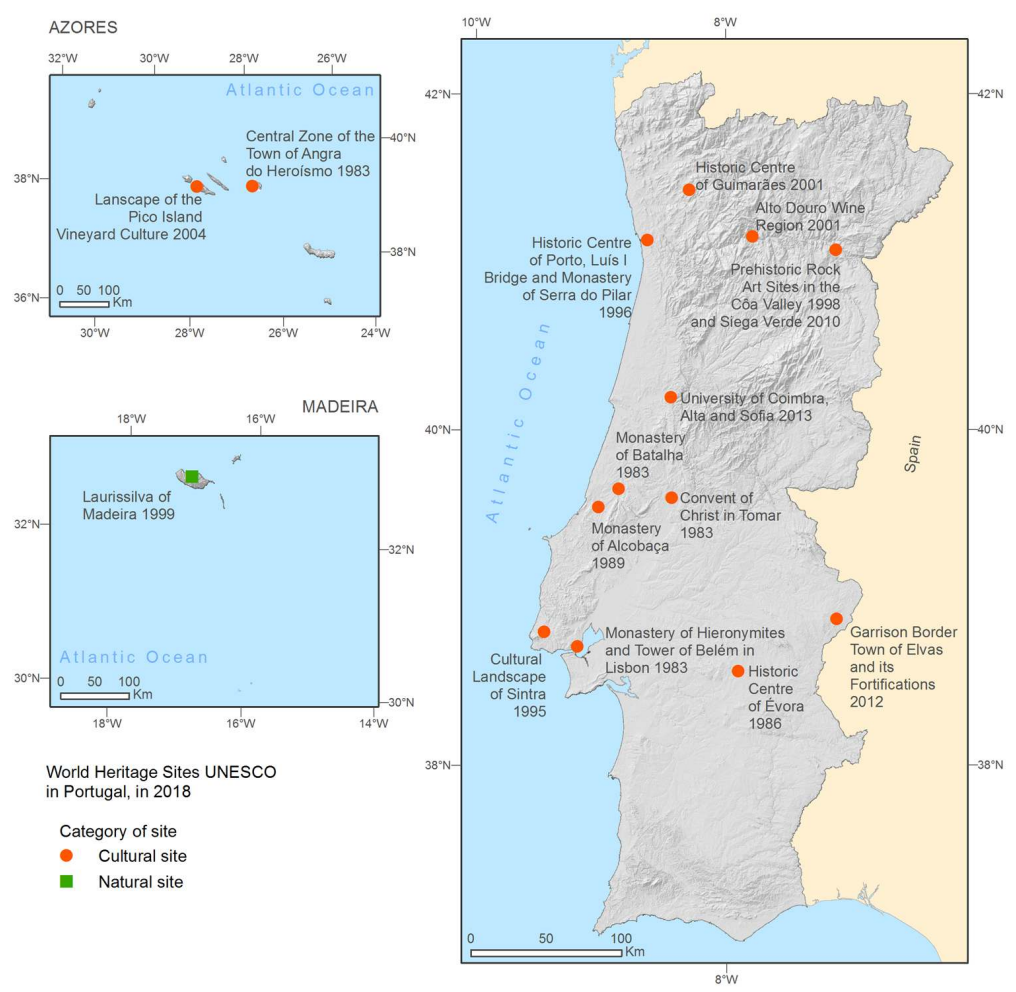

Source: Data from World Heritage Centre, UNESCO, 2018, map by Claudete Oliveira Moreira.

Fıg. 13 - Three World Heritage Sites 

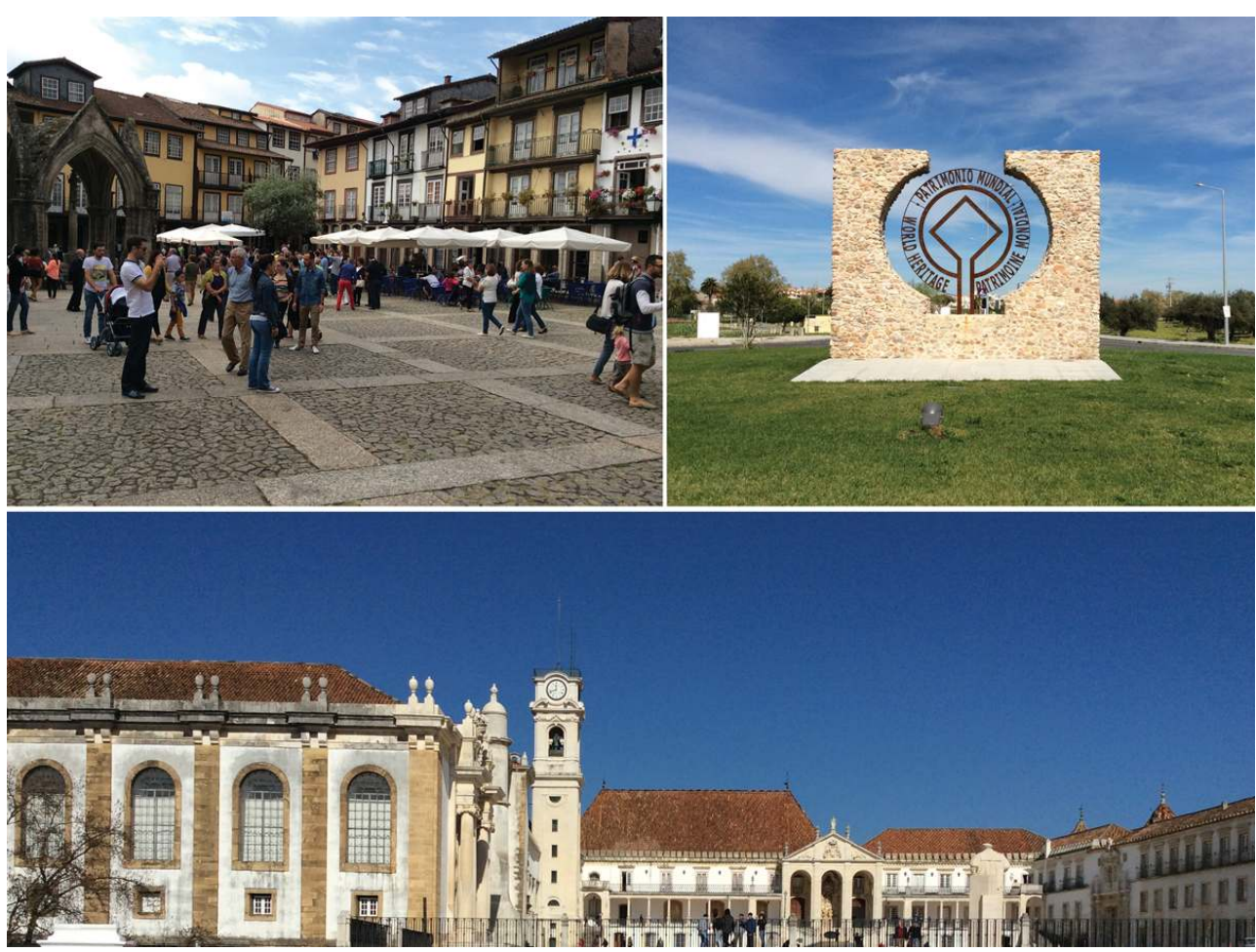

Top left: Historic Centre of Guimarães, World Heritage Site since 2001, detail of Largo da Oliveira, with the porch-roof houses typical of the 17th century.

Top right: One way to mark the territory, erecting the World Heritage Site symbol on the roundabouts of the main access road to Elvas, the Garrison Border Town of Elvas, and its Fortifications have been a World Heritage Site since 2012.

Below: The University of Coimbra is the oldest university in Portugal and one of the oldest in the world, founded in 1290. It has been part of the World Heritage Site (Universidade de Coimbra, Alta e Sofia) since 2013. The photo shows the Paço das Escolas, old Paço Real de Coimbra (Royal Palace of Coimbra) the king's residence between 12th and 15th centuries, one of the most visited attractions in the Centre Region and in Portugal. The building on the left, the Biblioteca Joanina (Joanina Library), is the main tourist attraction, built in Baroque style with opulence, using materials from the Portuguese Empire, has bibliographic collections from 16th, 17th and 18th centuries, which makes it one of the richest libraries in Europe; the Tower, icon of the University, has bells whose chimes regulate University life, and mark the soundscape; in front is the Sala dos Capelos, where academic ceremonies are held; on the right Colégio de São Pedro (Saint Peter's College), which is now the Rectory.

PHOTOS BY CLAUDETE OLIVEIRA MOREIRA, OCTOBER 2015, JULY 2015 AND FEBRUARY OF 2018, RESPECTIVELY.

Tourist activity in Portugal is still concentrated in terms of locations and territorial imbalances are striking, despite public and private investment in developing tourism in the interior and borderland territories (fig. 8, fig. 14, and fig. 15). In Portugal, tourism has been seen as an activity capable of strengthening territorial cohesion and contributing to the toning down of regional asymmetries. Yet, Lisbon, Algarve, and Madeira are the epicenters of tourism in Portugal. These destinations demonstrate a greater level of internationalization of tourist demand and higher average length of stay. They are wellestablished destinations, which became more important in the 1960s, thanks in no small measure to the building of international airports. Figures 8, 14 and 15 illustrate the territorial selectivity of tourist activity. The ability of municipalities to attract tourist demand differs (fig. 16). The Tourism Uptake Rate (TUR) in 2016 for Lisbon differs greatly from the other Portuguese municipalities. Lisbon absorbs $21.9 \%$ of the visitors, while Porto receives $7.71 \%$ and Albufeira, $7.36 \%$. All the other municipalities have a much lower rate of tourism, the fourth placed one is Funchal with $4.39 \%$, followed by two 
municipalities in the Algarve, Loulé (2.95\%) and Portimão (2.43\%). Only $6.1 \%$ of Portuguese municipalities have a Tourism Uptake Rate (TUR) above $1.00 \%$. Among these are municipalities that have important medium-sized cities and World Heritage Sites, namely, Coimbra (1.78\%), Évora (1.57\%) and Sintra (1.18\%). In spite of having World Heritage Sites Guimarães and Elvas have lower rates of $0.74 \%$ and $0.21 \%$, respectively. A. GUEDES and M. MARTÍN JIMÉNEZ (2015) illustrate the close spatial relation between cultural attraction density, particularly national monuments and UNESCO World Heritage Sites, and tourism. Note that it is not just municipalities with medium-sized cities and towns and sites inscribed on the UNESCO World Heritage List, such as Coimbra, Évora and Sintra that deserve a mention, but Ourém municipality, too, where the Fátima Marian Sanctuary is located (fig. 16). This is one of the world's most important centers of Christian pilgrimage (M. SANTOS, 2006), and in 2017 it celebrates the 100th anniversary of the apparitions of the Virgin Mary. Despite the concentration of development and tourism supply and demand in coastal areas, Portugal today, as a tourist destination, has new spatial identities, new regions, new nodes, new places, new resources, new products, new experiences, and new stakeholders. These are "different from the monolithic and highly concentrated paradigm that fostered Portuguese tourism development since the 1960s around the Algarve", the tour operators' conceptualization of mainland Portugal through written discourse (travel brochures) both reflect and contribute to this situation (GUEDES and MARTÍN JIMÉNEZ, 2016: 192). Some international newspapers and travel writers have also fostered the image of Portugal as a tourist destination. C. Santos (2004) identifies the frames used in travel sections in some American newspapers ( New York Times, Washington Post, Los Angeles Times, and USA Today) about tourism in Portugal and Portuguese people.

Fig. 14 - Number of hotel establishments in Portugal, in 2016
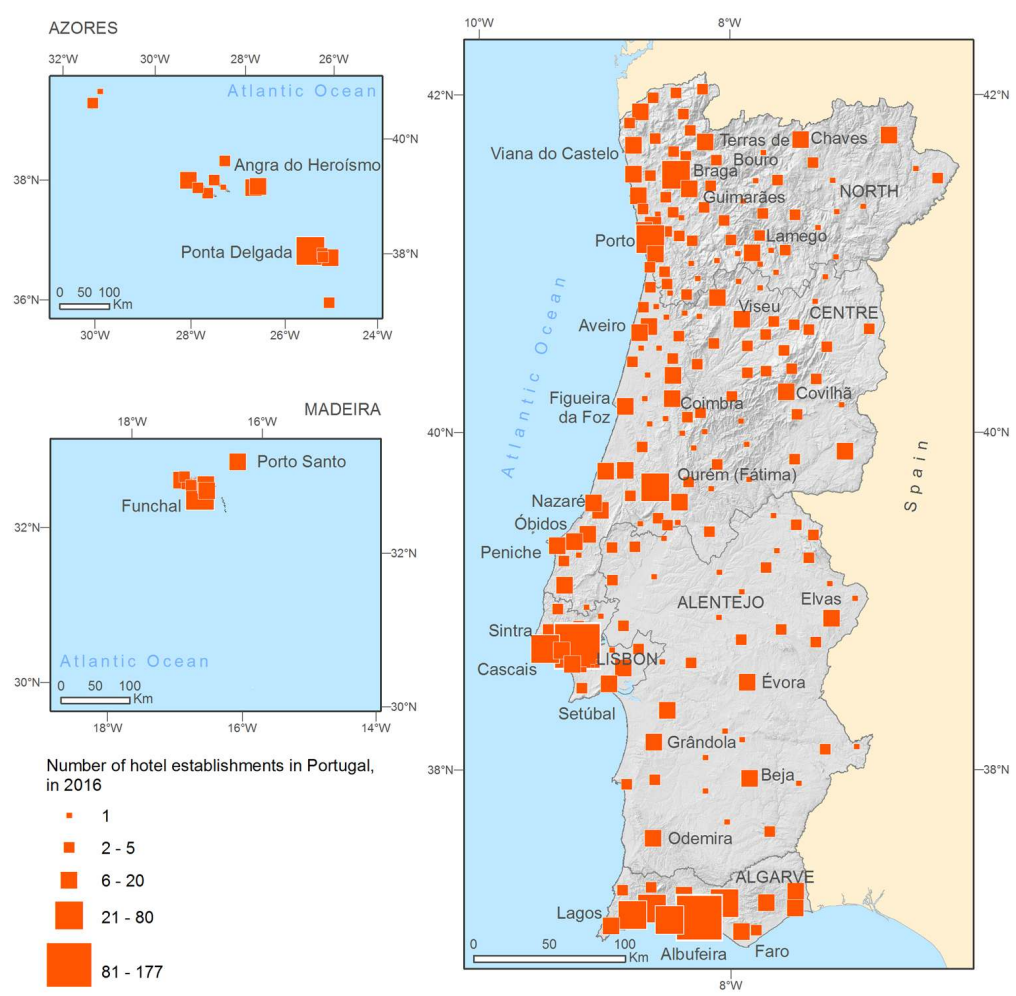

Source: Data from Instituto Nacional de Estatística, Lisbon, map by Claudete Oliveira Moreira. 
Fig. 15 - Number of rural tourism establishments in Portugal, in 2016

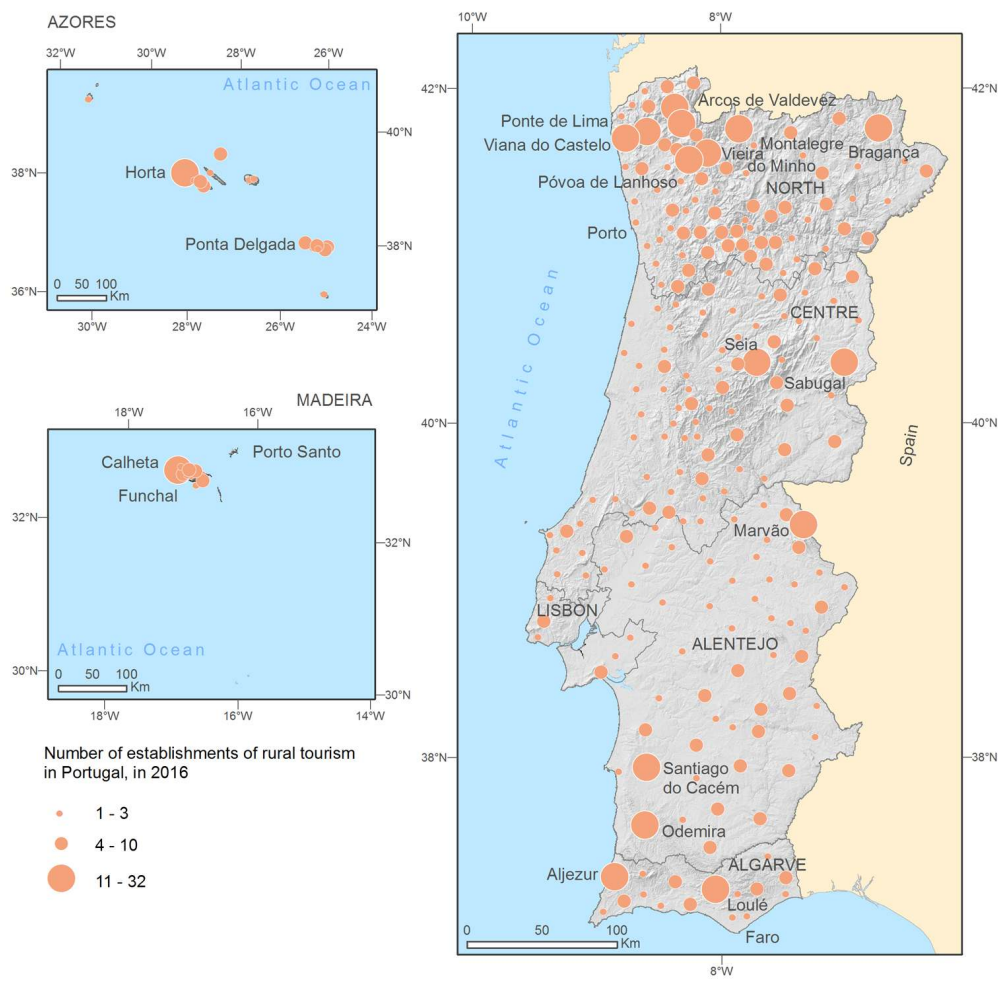

Source: Data resulting from specific information, Instituto Nacional de Estatística, Lisbon, map by Claudete Oliveira Moreira. 
Fig. 16 - Tourism Uptake Rate (TUR)* for Portuguese municipalities, in 2016
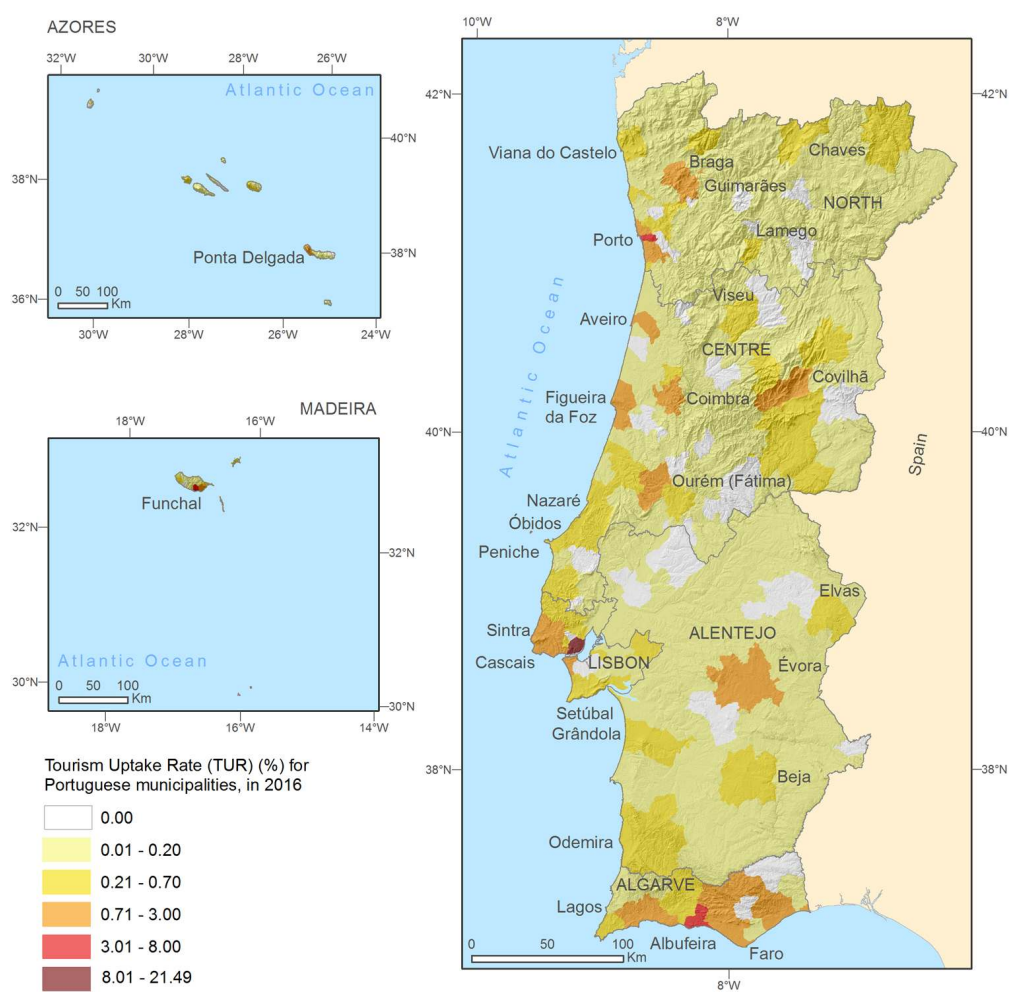

It means the capacity to attract visitors by each municipality, considering the total number of visitors to Portugal.

* Tourist Uptake Rate (TUR) for each municipality in Portugal:

$$
\text { TUR }_{c i}=\frac{N G_{C i}}{N G_{p}} \times 100
$$

Where,

$\mathrm{TUR}_{c i}=$ Tourist uptake rate of the municipality

$\mathrm{NG}_{c i}=$ Total number of guests in the municipality's accommodation establishments

$N_{G_{P}}=$ Total number of guests in accommodation establishments in Portugal

Source: Data from Instituto Nacional de Estatística, Lisbon, map by Claudete Oliveira Moreira.

Some interior destinations and Atlantic archipelagos of Azores and Madeira attract a tourist demand focused on rural tourism. Towards the end of the 1990s we witness a renovation of tourist enterprises and the rise of rural tourism, especially in the north, the NUT III Minho-Lima (KASTENHOLZ, 1997; KASTENHOLZ, 2002; KASTENHOLZ, 2004; CAVACO, 2005a; KASTENHOLZ, DAVIS and PAUL, 2009; MOREIRA and REIS, 2017) (fig. 15). It is in this decade that the Program to Rehabilitate Historical Villages appears, to be implemented on 12 villages from central Portugal (KASTENHOLZ, CARNEIRO, MARQUES and LIMA, 2012; SILVA and LEAL, 2015). The program was set up in 1994 with the help of the second Community Support Framework (1994-1999), and was developed further in the next Community Support Framework (2000-2006). In 2001 we had the Schist Villages' Program, covering a network of 27 villages in central Portugal with a high heritage value, with the goals of revitalizing and restoring the built heritage and the traditions, as well as valuing the landscape and endogenous resources. A tourist product was built up, rooted in housing, gastronomy, tourist recreational activities, nature tourism and adventure 
tourism, taking advantage of water courses by creating fluvial beaches. Since the 1990s, but particularly in the early $20^{\text {th }}$ century, inland waters have been exploited for nautical activities, boat trips, rowing, kayaking, canyoning, rafting, among others (MOREIRA and SANTOS, 2010; MOREIRA, 2012). The Alqueva reservoir, the largest artificial lake in Europe covering $250 \mathrm{~km}^{2}$, appeared in Alentejo in 2002. It became a tourist destination for some of these activities and rural tourism (fig. 15). A. RODRIGUES (2015) explored the destination images and this 'waterscape.' Various initiatives have been launched since the 1990s, which enabled low density regions to emerge as tourist destinations (see CARVALHO and FERNANDES, 2001; BRITO-HENRIQUES, 2008; SANTOS and CUNHA, 2008; SILVA and CARVALHO, 2011; CARVALHO, 2012). Nevertheless C. EUSÉBIO, M. CARNEIRO, E. KASTENHOLZ, E. FIGUEIREDO and D. SILVA (2017) noted that in Portugal tourism is highly concentrated in coastal areas, with the socioeconomic contribution of rural tourism being still limited. J. ANDRAZ, N. NORTE, and H. GONÇALVES (2015) found that benefits from tourism are not equally distributed among Portuguese mainland regions; the Algarve emerges as the most important tourist region, followed by Lisbon, the Centre, North, and finally, Alentejo.

Within Portugal, the provision of wellness tourism products is also relevant to tourist demand. In 2018, Portugal had 40 spa resorts, which are mostly concentrated in northern and central Portugal. The spas of Vidago-Pedras Salgadas, Curia, Luso, Monte Real and Caldas da Rainha were very popular in the mid-1960s. The first Jornadas do Termalismo Português (Conference of Portuguese Balneology), in 1978, shows the decline of this activity and the neglect that these resorts were starting to suffer (CAVACO, 2005b; RAMOS , 2005; MANGORRINHA, 2012; CUNHA, 2012). The Comissão Nacional do Termalismo (National Commission of Balneology) was set up in 1986 to boost the appeal of thermal resorts as a tourist product. It was considered that promoting this product would help to even out regional asymmetries. It was only in the $21^{\text {st }}$ century when Portugal's spa resorts were modernized and upgraded that they targeted well-being while continuing to exploit the therapeutic qualities of the waters. In 2004 the spa industry was finally regulated and structured by upgrading and revamping the facilities at the spa resorts, as well as introducing innovative products (PORTUGAL, 2004). The first contemporary tourist recreational spa complex was opened in Unhais da Serra in 2010. N. GUSTAVO (2010) highlighted another recent tendency in Portugal, namely, the proliferation, mainly in urban areas, of new spaces integrated into hotels within the modern concept of the spa.

Tourist products in low density regions find suitable sites for nature tourism activities in the Network of Protected Natural Areas, areas that occupy 21\% of the national territory (see CARNEIRO, 2007; FERNANDES, 2012; CRAVIDÃO and CUNHA, 2017; GAVINHO and SILVA, 2017). In Portugal in 2018 (March), there were 5,179 tourist entertainment operators, of which $13.8 \%$ were engaged in nature tourism activities (TP, 2018). Gastronomy and wines are another very important country-wide asset, one which diversifies and enhances the tourist product. Gastronomy was elevated to national heritage status in 2000 , since Portuguese culinary traditions are both rich and varied. In terms of wine, Portugal has 29 DOC wine regions, thus ensuring that Portuguese wines are varied in character and of high quality. A great many activities related to wine tourism are organized in several regions, like Alentejo, Bairrada, Dão, Douro, among others. Local and regional stakeholders try to increase the regional attractiveness and competitiveness associated with endogenous products and services, through the design and development a strategic policy (see, in BRÁS, COSTA and BUHALIS, 2010 the case study of Bairrada). 
The quality of tourist experiences provided by this product depends significantly on having skilled human resources. It was in the 1960s that the first degrees in tourism were created in Portugal, in the Instituto Superior de Línguas e Administração de Lisboa (ISLA) (Higher Institute of Languages and Administration of Lisbon) and the Instituto Superior de Novas Profissões (INP) (Institute of New Professions). The Centro Nacional de Formação Turística e Hoteleira (National Centre for Tourism and Hotel Training) was established in 1965. The recognition of the importance of education and training in tourism led to the creation of a strategic plan for training in tourism 1991-1996. Today, Portugal has a network of 12 hotel and tourism schools. These are run by Turismo de Portugal, the national tourist authority, and are located in areas with potential for growth in tourism. These schools maintain a close relationship with the local community and the regional stakeholders and they focus on highly specialized, eminently practical, training, i.e., the technical mastery of culinary and baking skills, catering and beverages, tourist operations and hotel management, certifying, training and updating human resources. Apart from initial training, they provide continuous training to working professionals to ensure permanent improvement and updating of skills, which is an essential element in the service quality and competitiveness of Portugal. They are places of innovation, too. The first tourism and hotel school was established in Portugal in 1957, in Lisbon. The last 50 years have seen a further of tourism and hotel schools almost half of them appearing in the first decade of the 21st century (MOREIRA, 2013; MOREIRA, 2016). Whereas in the 1960s and 1970s they tended to be established in the main tourist destinations of Lisbon, Estoril, Faro, Portimão and Porto, in the 1980s they were decentralized and set up further inland, in Coimbra and Santa Maria da Feira. This last one, together with the schools set up in the spa resorts of Luso and Vidago, were branches of the Porto tourism and hotel school. In terms of higher education, the undergraduate degree in tourism was offered by 29 educational institutions in 2018, mainly in polytechnic institutions (public: 10 institutions, private: 8 institutions), followed by universities (public: 6 institutions, private: 5 institutions).

\section{4 - Tourism Planning in Portugal}

In the 1960s we see for the first time a reference to tourism as part of a planning instrument in Portugal. It came in the Plano Intercalar de Fomento (Interim Development Plan) (1965-1967)-there is no reference to tourism in the I Plano de Fomento ( $1^{\text {st }}$ Development Plan) (1953-1958) and in the II Plano de Fomento (2nd Development Plan) (1959-1964). However, the importance of investing in hotel capacity aimed at luxury tourism instead of mass tourism is stressed in the Interim Development Plan (CAVACO , 1979; CÂMARA, 2004). The III Plano de Fomento (3rd Development Plan) (1968-1973) considered tourism to be a strategic sector of economic development, with the understanding that it is the foreign market that leads the expansion of hotel capacity and complementary tourist activities.

41 Portugal found it difficult for decades to define a policy for tourism, organizing and planning activities in both the medium and the long run (COSTA and VIEIRA, 2014). Tourist planning was virtually non-existent in Portugal until the 1980s. The first Plano Nacional de Turismo (National Tourism Plan) was a medium-term plan that was enacted and published in 1986. It remained in force until 1989, being recognized as an important change in tourism policies in Portugal (ARROTEIA, 1994; COSTA, 1996; KASTENHOLZ, 1997; 
VIEIRA, 2007; SIMÕES, 2008; MANGORRINHA, 2012; ALMEIDA GARCIA, 2014; SILVA, 2017). Under this plan, 19 Regional Tourist Boards were created, following a policy approach to decentralize state power that saw some importance ascribed at both a local and regional scale; land-use planning was valued, as well as investments, professional training, tourist entertainment, balneology and spas and promotion aimed at diversifying markets and increasing revenues.

In 2006 the Plano Estratégico Nacional do Turismo (PENT) (National Strategic Plan for Tourism) (2006-2015) was drawn up (MEI, 2007). It was approved in 2007 and became the strategic framework for developing tourism in Portugal, over a ten-year period. The goals of this plan were:

- to reorganize the organic and institutional structure of tourism both nationally and regionally by investing in the simplification of tourism planning in Portugal. Eleven regional tourism bodies were set up in mainland Portugal (in the form of five Regional Tourism Authorities and six Tourist Development Centers), along with two Regional Tourism Directorates in Azores and Madeira. Previously, there were 27 regional and local bodies in mainland Portugal and two in the Autonomous Regions responsible for the management of the destinations and product structuring; the external promotion of the regions was left to the Regional Tourist Promotion Agencies;

- to diversify the offering, which is why 10 strategic tourist products were structured and developed for the first time, namely: cultural and landscape tours; sun and sea; nature tourism; city break; gastronomy and wines; integrated resorts and residential tourism; business tourism; golf; health and wellness; nautical tourism;

- to promote and organize events that would project national destinations abroad;

- to strengthen the public and private investment in tourism.

This plan was revised in 2010, for the timeframe 2013-2015 (MEE, 2013). The revision was required due to the effects of the international economic and financial crisis, which began to be felt in 2008, the rise of low-cost air travel, the decline in charter flights, the growing demand for short breaks, the importance of new information and communication technology, and other factors. This revision aimed at the more sustainable development of tourism, the regions and local communities, together with a better qualified and competitive product. In addition, there have been investments in a wider range of experiences, with the emphasis on unique, remarkable and authentic experiences, with events contributing a great deal to enhancing these experiences. When it comes to tourist products, there was an intention to develop strategic products; some were readjusted, such as cultural and landscape tours, with the emergence of tourist, religious and cultural routes. Religious tourism was singled out due to the importance of the Marian cult pilgrimages (where Fátima's Sanctuary is particularly important), the Portuguese Central Way of St James (Camino de Santiago), and the Jewish quarters. To these were added the bolstering of access by air and distinct strategies for the sending countries, along with better online promotion and distribution. In terms of tourist planning, since 2013 mainland Portugal has been organized into five Regional Tourism Areas and in five Regional Tourism Authorities (PORTUGAL, 2013), still with two Regional Tourism Directorates in Azores and Madeira.

Currently the prevailing planning instrument is Turismo 2020: Plano de Ação para o Desenvolvimento do Turismo em Portugal (Tourism 2020: Action Plan for Tourism Development in Portugal) 2014-2020 (TP, 2015). This plan, which follows the Community Programming cycle, established goals and investment priorities as a way of creating 
selectivity, allocating the European structural and investment funds more effectively, strengthening sectorial and territorial coordination, and enhancing networks and ways of collaboration.

The Estratégia Turismo 2027 (Tourism Strategy 2027) was set up at the same time (TP, 2017). Its purpose is to create a strategic framework for tourism to follow the next cycle of Community Programming 2021-2027. The Tourism Strategy 2027 intends to combine the short-term action, i.e., in the 2020 horizon (Tourism 2020: Action Plan for Tourism Development), with the long-term strategic and structural perspective of tourism in Portugal, for the next 10 years. Tourism Strategy 2027 includes a national marketing plan, a tourism school development plan and regional tourism plans. Once again a broader participation in the planning process is sought as well as consultation between the public and private key players and stakeholders (regional tourism authorities, local governments, intermunicipal communities, business associations, entrepreneurs and the national scientific and technological system). The goal is to define a strategy that will not only be participatory but also open, dynamic (keeping track of markets and trends), and shared by the various economic activities that are a part of tourism, with the government being responsible for mobilizing both the stakeholders and society. Ten strategic assets are set out in it:

- Five differentiating assets, namely, weather and light, nature and biodiversity, water, history and culture, sea.

- Two qualifying assets, which are gastronomy and wines, artistic, cultural, sports, and business events.

- Two emerging assets, which are wellness and living in Portugal. This is thanks to the safety, climate, cost of living, quality of life, gastronomy and wines, natural and cultural heritage, and medical tourism, which encourages more and more foreigners, investors, students and retirees to choose Portugal to live for weeks or months. There are Brazilians because of the historical links to the country and its location in Europe and Chinese people who are attracted by real estate investments and the golden visa, a special residence permit for foreigners (acquired through investment activity in Portuguese territory), created in 2012. Then we have retirees from northern and central Europe, for decades seeking out the south of the country, especially the Algarve, but also increasingly acquiring residences in the rural areas of the Centre and North of Portugal, and finally foreigners seeking health care provision and convalescence in Portugal, expanding the offer of medical tourism.

- One asset shared by all, which is the people - the residents, the visitors, and the professionals.

Five strategic axes are also included:

- promoting the territory,

- driving the economy,

- enhancing knowledge,

- generating connectivity,

- projecting Portugal.

\section{Conclusion}

47 Tourism became institutionalized in Portugal in 1911, with the creation of the first official tourism body: the Repartição de Turismo (Tourism Department). It was a pioneering project at the time because Portugal was only the third country to have an official 
tourism body, following Austria (1909) and France (1910). From then on the main goal of the key players and stakeholders linked with tourism was to advocate Portugal as one of the main tourist destinations in Europe. In the last 50 years various initiatives and action measures have been implemented to structure and consolidate tourism, as well as the competitiveness of the destination.

The 1960s were a time of considerable growth of tourist demand and structuring of the offering, much of it through private initiative, which started targeting tourist investments on the coast. The State was responsible for regulation and inspection, and for fostering private initiatives by creating judicial, financial (Tourism Fund), and administrative support. However an economic perspective of tourism prevailed. The development plans, namely the Interim Development Plan and the 3rd Development Plan, promoted international tourist demand and, in terms of products, the high-end, luxury and first-class hotels. The activity's dynamism made it possible for the Portuguese National Statistics Institute (INE) to start publishing tourism data systematically in this decade, providing figures for which the first reference year was 1964. The 1960s were equally characterized by the creation of the main national airports and the promotion of education and training in tourism with the creation of the National Centre for Tourism and Hotel Training.

In the 1970s there have been investments in tourist destinations such as the Algarve, Madeira and Tróia, basing the tourist offering on the sun and sea product and targeting mass tourism. Two of the most significant tourist complexes inaugurated in this decade were the Vilamoura village (1966-1974) which provided apartment accommodation and single-family houses, green spaces, a marina, a casino and golf course, and Tróia (1970-1974), with a timesharing system of accommodation, a novelty in Portugal at that time. It was in the 1970s that businessmen started to get involved, as happened with travel agencies and restaurants.

In the 1980s there was a clear effort to set up public bodies connected to tourism, both national and regional, for strategic planning and upgrading the tourist product. The entry of Portugal in the EEC increased tourism growth. The tourist demand from the United Kingdom was particularly telling, representing almost $25 \%$ of overnight stays in accommodation establishments (table 1). Tourists included the sun seekers who headed for a developing destination: the Algarve. The first National Tourism Plan in Portugal dates from this decade, as well as a tendency to develop tourism locally and regionally to prevent it from revolving solely around Lisbon, the Algarve and Madeira.

51 The 1990s were extremely important for structuring the offering. Investment in road infrastructure boosted tourist investment, especially in low-density territories where tourism was seen as an opportunity for the demographic and economic revitalization. There was a diversification of the accommodation offered, with rural tourism gaining popularity. There was a significant investment in golf courses, too. Distinctive tourist developments were built as well as event venues, which led to a rise in international cultural, social and sporting events. The Secretaria de Estado do Turismo (Secretary of State for Tourism) determined the creation of the first Inventário dos Recursos Turísticos (Tourism Resources Inventory) in Portugal in 1990 (UMBELINO et. al., 1993), which was presented in 1996. A Livro Branco do Turismo (White Paper on Tourism) appeared in 1991 (DGT, 1991). This decade saw the liberalization of the European Community airspace and a consequent increase in competition, which induced greater efficiency, improved quality 
of service provision, and lower airfares. In the 1990s investments were also made in the management and promotion of Portugal, at home and abroad.

The first decade and half of the 21st century has been characterized by the structuring of new tourist products, the increase, diversification, and territorial dispersal of accommodation (Alentejo, Azores, North and Centre of Portugal), simplification of the creation of tourist enterprises and local accommodation facilities. Tourism entrepreneurship has become a business opportunity for small and medium-sized investors in the years following the economic and financial crisis. There are more incentives for companies to become internationalized and to value the qualification of human resources, along with quality, sustainability, innovation, and, lastly, competitiveness, as a way of reducing State intervention. Forms of cooperation and collaboration, institutional and territorial partnerships and networks have been intensified. Various key players and stakeholders have been mobilized to set policies and strategies for tourism in the medium and long run. Furthermore, there has been a political and social recognition of the importance of tourism, with a basic law on tourism being published in 2009, and a Tourism Satellite Account for Portugal being created in 2006.

The strong, fast growth of tourism in Portugal since 2012 has posed some problems for the destination and the components of the tourism system, in particular:

- the shortage of qualified human resources;

- the persistent low pay of many of the people employed in tourism;

- there is still a marked concentration of tourist demand in Portugal, and it is proving hard to spread tourist demand around the country and among tourist attractions;

- some particularly striking problems appear in the main cities of Lisbon and Porto. There has been an increase in tourism pressure on the facilities and public infrastructure in cities, which is why some local authorities have tried to levy tourist taxes on overnight stays, with the revenue being invested in tourist attractions and/or the cleaning of public areas. Even so, the measure is recent and not yet widespread in Portugal, being limited to Lisbon and Santa Cruz on the island of Madeira (since January 2016, and Lisbon is due to reassess the value in January 2019), Cascais (since February 2017), Porto (since March 2018), Vila Nova de Gaia (since April 2018);

- she supply of local accommodation has multiplied but has tended to concentrate in city centers and all too often in apartment blocks, where the conduct and pace of life of tourists can interfere with that of the residents. This situation is particularly conspicuous in Lisbon and Porto. There has been a significant increase in the price of property and rents in city centers. The cost of living has risen in city centers, with higher costs for the residents in the acquisition of goods and of services, as prices become unaffordable for a middle class that is being forced to leave the central areas;

- conflicts have started to arise between residents and local authorities due to the operating hours of nightlife establishments, noise and disturbance of peace and quiet in public spaces where residential and leisure facilities are next door to one another (in the case of the medium-sized city of Coimbra see SANTOS and MOREIRA, 2012);

- come streets in the historic centers of the large and some medium-sized cities are dominated by catering and souvenir outlets;

- tourists use the public transport services that connect the main tourist attractions constantly and intensively, especially in Lisbon and Porto; 
- there is constant traffic movement in the narrow streets where much of the important heritage is found, with occasional oversized transport in central areas. Traffic flow and parking difficulties have led Lisbon City Hall to restrict the occasional transport of passengers in some streets of the historic center (since August 2017);

- the unregulated spread of camper-vans and caravans is particularly apparent on the Alentejo and Algarve coasts. This demand is year-round but it intensifies in the winter, with impacts on ecosystems, landscapes and spatial planning;

- leisure cruises on rivers and estuaries such as the Douro, Tagus, Sado, Vouga and Guadiana are becoming increasingly popular. Sea cruise vessels are having an appreciable environmental impact on the aquatic environments of cities such as Funchal, Lisbon and Matosinhos.

In spite of this over the last 50 years the tourist offer in Portugal has grown very significantly, to become diverse and distinctive as new tourist products and attractions have appeared to make the destination more distinctive. Gastronomy and wines have helped to exceed expectations. Innovation in accommodation and catering has created differentiation and distinctiveness. By staging major events Portugal has been able to project itself internationally. Investment has been made in the image, the promotion and marketing of Portugal as a destination, and national and international tourist demand have both grown as a result. The marked seasonality of tourist demand has been fading, so Portugal can start to assert itself as a year-round destination. Tourism has helped employment, investment, exports, development of the maritime economy, the regeneration of public spaces, the rehabilitation of properties built in the historic centers of medium-sized Portuguese cities, and encouraged people to settle in inland low density regions, enhancing territorial cohesion and balance. Currently the efforts of the key players and stakeholders, both public and private, are converging to strengthen the competitiveness of the destination.

The dynamics of tourism in Portugal is so marked today that the costs and benefits of this activity need to be assessed, and those responsible for destination management and attractions must strive for sustainability and quality as the cornerstone of competitiveness.

\section{BIBLIOGRAPHY}

AGÊNCIA PORTUGUESA DO AMBIENTE (APA), (2017), Classificação da qualidade das águas balneares, 2016, Agência Portuguesa do Ambiente, Lisboa, [online].

ALMEIDA GARCIA F., (2014), A comparative study of the evolution of tourism policy in Spain and Portugal, Tourism Management Perspective, no. 11, p. 34-50.

ALMEIDA J., COSTA C., SILVA F. N., (2017), A framework for conflict analysis in spatial planning for tourism, Tourism Management Perspectives, no. 24, p. 94-106.

ANDRAZ J. M., NORTE N. M., GONÇALVES H. S., (2015). Effects of tourism on regional asymmetries: Empirical evidence for Portugal, Tourism Management, no. 50, p. 257-267. 
ANDRAZ J. M., RODRIGUES P. M. M., (2016), Monitoring tourism flows and destination management: Empirical evidence for Portugal, Tourism Management, no. 56, p. 1-7.

ARROTEIA J. C., (1994), o turismo em Portugal: subsídios para o seu conhecimento, Fundação João Jacinto de Magalhães, Col. Cadernos Turismo e Sociedade, Aveiro, 94 p.

BANCO DE PORTUGAL (BP), (2018), Estatísticas do Banco de Portugal, [online].

BRÁS J. M., COSTA C., BUHALIS D., (2010), Networks analysis and wine routes: The case of the Bairrada wine route, Portugal, The Services Industries Journal, no. 30, 10, p. 1-21.

BRITO-HENRIQUES E., (2008), Representações da insularidade e turismo: que possibilidades para as ilhas portuguesas? in CAVACO C. (coord.), Turismo, inovação e desenvolvimento: Atas do I Seminário: turismo e planeamento do território, Centro de Estudos Geográficos, Lisboa, p. 123-142.

CÂMARA M. B. C., (2004), The development of the Portuguese hotel business, 1950-1995, Working Paper, Centro de Estudos de Economia Aplicada do Atlântico, Universidade da Madeira, Funchal, 35 p., [ online].

CARNEIRO M. J., (2007), Modelling the choice of tourism destinations: a positioning analysis, $\mathrm{PhD}$ thesis, University of Aveiro, Aveiro, 492 p. [online].

CARVALHO P., (2012), Planeamento, turismo e património em territórios de baixa densidade, in CARVALHO P., Ordenamento e desenvolvimento territorial, Imprensa da Universidade de Coimbra, Coimbra, p. 107-127.

CARVALHO P., FERNANDES J. L. J., (2001), Iniciativas de desenvolvimento local no espaço rural português: o exemplo do Leader Eloz (entre Lousã e Zêzere), in CAETANO L. (Coord.), Território, inovação e trajetórias de desenvolvimento, Centro de Estudos Geográficos, Universidade de Coimbra, Coimbra, p. 241-271.

CASTET J.-B., (2008), Les sites des expositions de Séville, Lisbonne et Saragosse: de l'éphémère au durable?, Méditerranée, no. 111, p. 103-107.

-, (2010), L'impact des expositions internationales et universelles sur les métropoles de la Péninsule Ibérique: Séville/Lisbonne/Saragosse, Méditerranée, no. 114, p. 113-120.

CAVACO C., (1979), o turismo em Portugal. Aspectos evolutivos e espaciais, Universidade de Lisboa, Lisboa, $52 \mathrm{p}$.

-, (2005a), Diferenciação regional da função turística, in MEDEIROS C.A. (Dir.), Geografia de Portugal, Círculo de Leitores, Rio de Mouro, p. 385-399.

-, (2005b), Os espaços de turismo, in MEDEIROS C. A. (Dir.), Geografia de Portugal, Círculo de Leitores, Rio de Mouro, p. 408-422.

CORFU A., BREDA Z., COSTA C., (2006), EU integration and tourism destination management: The case of Portugal, Amfiteatru Economic Journal, no. 8, p. 20-29.

CORREIA A., KOZAK M., (2012), Exploring prestige and status on domestic destinations: The case of Algarve, Annals of Tourism Research, no. 39, 4, p. 1951-1967.

COSTA C., (1996), Towards the improvement of the efficiency and effectiveness of tourism planning and development at the regional level: Planning and networks. The case of Portugal, $\mathrm{PhD}$ thesis, University of Surrey, Guildford, 509 p.

COSTA C., VIEIRA A. L., (2014), Tourism planning and organization in Portugal, in COSTA C., PANYIK E., BUHALIS D., (Eds), European tourism planning and organization systems: the EU Member States, Channel View Publications, Bristol, p. 352-366. 
CRAVIDÃO F., CUNHA L, (2017), Turismo em espaços litorais: onde o mar começa e a terra se renova, in SILVA F., UMBELINO J., (coord.), Planeamento e desenvolvimento turístico, Lidel, Lisboa, p. 425-433.

CUNHA L., (2012), Turismo em Portugal: sucessos e insucessos, Edições Universitárias Lusófonas, Lisboa, $617 \mathrm{p}$.

DIONÍSIO J. P., (2012), Políticas públicas para a promoção da imagem externa, in RODRIGUES M. L., SILVA P. A. (org.), Políticas públicas em Portugal, Imprensa Nacional Casa da Moeda, ISCTE, Instituto Universitário de Lisboa, Lisboa, p. 439-450.

DIRECÇÃO GERAL DO TURISMO (DGT), (1991), Livro Branco do Turismo, Secretaria de Estado do Turismo, Lisboa, $174 \mathrm{p}$.

DOMINGUES C. M., (2000), 4 décadas de Turismo. Contributo de uma instituição, Instituto de Financiamento e Apoio ao Turismo, Lisboa, 119 p.

EUSÉBIO C., CARNEIRO M. J., KASTENHOLZ E., FIGUEIREDO E., SILVA D. S., (2017), Who is consuming the countryside? An activity-based segmentation analysis of the domestic rural tourism market in Portugal, Journal of Hospitality and Tourism Management, no. 31, p.197-210.

FERNANDES J. L., (2012), Parques naturais e outras áreas classificadas no modelo de desenvolvimento português, Terras de Sena, Seia, $537 \mathrm{p}$.

FIGUEIRA DE SOUSA J., FERNANDES A., CARPINTEIRO A., (2009), Developing nautical recreational activities as a territorial strategy: A perspective on the Tagus Estuary, Journal of Coastal Research, SI 56, p. 1154-1158, [online].

GAVINHO E. C., SILVA M., (2017), Espaços naturais: o desafio de planear um destino turístico, in SILVA F., UMBELINO J., (coord.), Planeamento e desenvolvimento turístico, Lidel, Lisboa, p. 451-464.

GUEDES A. S., MARTÍN JIMÉNEZ M. I., (2015), Spatial patterns of cultural tourism in Portugal, Tourism Management Perspectives, no. 16, p. 107-115.

GUEDES A. S., MARTÍN JIMÉNEZ M. I., (2016), Conceptualizing Portugal as a tourist destination through the textual content of travel brochures, Tourism Management Perspectives, no. 20, p. 181-194.

GUSTAVO N. S., (2010), A 21st century approach to health tourism spas: The case of Portugal [Special section], Journal of Hospitality and Tourism Management, no. 17, p. no. 127-135.

INSTITUTO NACIONAL DE ESTATÍSTICA (INE), (2005), Estatísticas dos Transportes 2004, Instituto Nacional de Estatística, Lisboa.

INSTITUTO NACIONAL DE ESTATÍSTICA (INE), (2017a), Anuário Estatístico de Portugal 2016, Instituto Nacional de Estatística, Lisboa, [online].

-, (2017b), Estatísticas dos Transportes e Comunicações 2016, Instituto Nacional de Estatística, Lisboa. INTERNATIONAL CONGRESS AND CONVENTION ASSOCIATION (ICCA), (2017), ICCA Statistics Report Country \& City Rankings 2016, International Congress and Convention Association, Amsterdam. [ online].

KASTENHOLZ E., (1997), The background and market profile of tourism in rural areas in the Portuguese North and Central Region, Master Thesis, University of Aveiro, Aveiro, 188 p. [online].

-, (2002), The role and marketing implications of destination images on tourist behavior: The case of Northern Portugal, PhD Thesis, University of Aveiro, Aveiro, 344 p., [online]. 
-, (2004), 'Management of Demand' as a tool in sustainable tourist destination development, Journal of Sustainable Tourism, no. 12, 5, p. 388-408.

KASTENHOLZ E., CARNEIRO M. J., MARQUES C. P., LIMA J., (2012), Understanding and managing the rural tourism experience, The case of a historical village in Portugal, Tourism Management Perspectives, no. 4, p. 207-214.

KASTENHOLZ E., DAVIS D., PAUL G., (1999), Segmenting tourism in rural areas: The case of north and central Portugal, Journal of Travel Research, no. 37, 4, p. 353-363.

LOPES F., GAMBOA T., (coord.), (2001), 90 anos de turismo em Portugal: conhecer o passado, investir no futuro, Ministério da Economia, Conselho Sectorial do Turismo, Lisboa, 47 p.

MANGORRINHA J. (coord.), (2012), História de uma viagem: 100 anos de turismo em Portugal (1911-2011) , Turismo de Portugal, Comissão Nacional do Centenário do Turismo de Portugal, Ponta Delgada, vol I, 371 p., vol II, 315 p.

MINISTÉRIO DA ECONOMIA E DA INOVAÇÃO (MEI), (2007), Plano Estratégico Nacional do Turismo. Para o Desenvolvimento do Turismo em Portugal 2006-2015, Ministério da Economia e da Inovação e Turismo de Portugal, Lisboa, [online].

MINISTÉRIO DA ECONOMIA E DO EMPREGO (MEE), (2013), Plano Estratégico Nacional do Turismo: Revisão e Objetivos 2013-2015, Lisboa, Ministério da Economia e do Emprego e Turismo de Portugal. [ online].

MOREIRA C. O., (2012), Lazer, animação turística e desenvolvimento local, in JACINTO R., (coord.), Patrimónios, territórios e turismo cultural: Recursos, estratégias e práticas, Coleção Iberografias, 19, Centro de Estudos Ibéricos, Âncora Editora, Guarda, p. 77-103.

-, (2013), Turismo, território e desenvolvimento: competitividade e gestão estratégica de destinos, Tese de Doutoramento em Turismo, Lazer e Cultura, Universidade de Coimbra, Coimbra, 892 p.

-, (2016), o turismo em Portugal: dinâmicas territoriais, coesão e competitividade, in JACINTO R., CABERO DIÉGUEZ V., (coord.), Diálogos (trans)fronteiriços: patrimónios, territórios e culturas, Iberografias, 31, Centro de Estudos Ibéricos, Nova Âncora, Guarda, p. 141-165.

MOREIRA C. O., FIGUEIREDO A., (2017), Turismo, lazer e património natural no destino Madeira, in CRAVIDÃO F., CUNHA L., SANTANA P., SANTOS N., (org.), Espaços e tempos em Geografia Homenagem a António Gama, Imprensa da Universidade de Coimbra, Coimbra, p. 595-622.

MOREIRA C. O., SANTOS N. P., (2010), New opportunities for water environments: River tourism and water leisure activities, in BRITO-HENRIQUES E., SARMENTO J., LOUSADA M. A. (Eds.), Water and tourism. Resources management, planning and sustainability, Centro de Estudos Geográficos, Universidade de Lisboa, Lisboa, p. 147-168. [online]

MOREIRA C. O., SANTOS N. P., (2016), Turismo fluvial em Portugal Continental: oferta e potencialidades, in NUNES A., MOREIRA C. O., PAIVA I., CUNHA L., Territórios de água, water territoires, CEGOT, Centro de Estudos de Geografia e Ordenamento do Território, Coimbra, p. 255-271.

MOREIRA F. J., REIS J., (2017), Os espaços rurais e o turismo, in SILVA F., UMBELINO J., (coord.), Planeamento e desenvolvimento turístico, Lidel, Lisboa, p. 435-450.

PINA M. H., (2007), O Alto Douro: um espaço contrastante em mutação, Imprensa Nacional Casa da Moeda, Lisboa, $1,214 \mathrm{p}$.

PINA P. M., (1988), Portugal: o turismo no século XX, Lucidus, Lisboa, 255 p. 
PORTUGAL, (2004), Decreto-Lei no142/2004 de 11 de Junho, Diário da República, 1. a série A-№ 136 - 11 de Junho de 2004.

PORTUGAL, (2013), Lei n.ํ3/2013, de 16 de maio, Diário da República, 1. érie A-№ 94 - 16 de maio de 2013, [online].

PRESIDÊNCIA DO CONSELHO DE MINISTROS (PCM), (2011), Relatório do Grupo de Trabalho da Internacionalização e Desenvolvimento, [online].

RAMALHO J., (2013), Os grandes eventos e a promoção da imagem externa de Portugal, Janus, no. 15 , p. 60-61. [online].

RAMOS A. R. C. de C.V., (2005), o termalismo em Portugal: dos factores de obstrução à revitalização pela dimensão turística, Tese de Doutoramento, Universidade de Aveiro, Aveiro, 658 p., [online].

RODRIGUES A. I. B. P., (2015), Lake-destination image assessment: The case of the Alqueva lake, Portugal, $\mathrm{PhD}$ Thesis in Tourism, University of Algarve, 309 p. [online].

SANTOS C. A., (2004), Framing Portugal, representational dynamics, Annals of Tourism Research, no. 31,1 , p. 122-138.

SANTOS M. da G. M. P., (2006), Espiritualidade, turismo e território: estudo geográfico de Fátima, Princípia, São João do Estoril, 702 p.

SANTOS N. P., CUNHA L. S., (2008), Novas oportunidades para o espaço rural: análise exploratória no Centro de Portugal, in SANTOS N. P., GAMA A., (coord.), Lazer da libertação do tempo à conquista das práticas, Imprensa da Universidade de Coimbra, Coimbra, p. 209-225, [online]

SANTOS N. P., MOREIRA C. O., (2012), Evening/night-time leisure in Coimbra, in VALENÇA M., CRAVIDÃO F. D., FERNANDES J. A. R., Urban developments in Brazil and Portugal, studies of Portuguesespeaking countries, Nova Science Publishers, New York, p. 317-338.

SERRA J., CORREIA A., RODRIGUES P. M. M., (2014), A comparative analysis of tourism destination demand in Portugal, Journal of Destination Marketing \& Management, no. 2 p. 221-227.

SILVA J., (2017), Planeamento e desenvolvimento turístico, in SILVA F., UMBELINO J., (coord.), Planeamento e desenvolvimento turístico, Lidel, Lisboa, p. 21-47.

SILVA L., LEAL J., (2015), Rural tourism and national identity building in contemporary Europe: Evidence from Portugal, Journal of Rural Studies, no. 38, p. 109-119.

SILVA S., CARVALHO P., (2011), Programas e sistemas de incentivos europeus com incidência na atividade turística em espaço rural: o exemplo do PRIME (Portugal, 2000-2006), in FIGUEIREDO E., (coord.), O rural plural: olhar o presente, imaginar o futuro, 100Luz, Castro Verde, p. 315-328.

SILVEIRA L., (2016), O turismo de iates: estratégia de desenvolvimento para a Figueira da Foz, Tese de doutoramento em Turismo, Lazer e Cultura, Universidade de Coimbra, Coimbra, 505 p., [online]. SIMÕES J. M., (2008), Turismo, ordenamento e sustentabilidade do território: problemas e desafios, in CAVACO C., (coord.), Turismo, inovação e desenvolvimento: Atas do I Seminário: turismo e planeamento do território, Centro de Estudos Geográficos, Lisboa, p. 341-393.

SIMÕES J. M., FERREIRA C. C., (2017), Sol, mar e praia: da vilegiatura balnear à reinvenção do produto turístico, in SILVA F., UMBELINO J., (coord.), Planeamento e desenvolvimento turístico, Lidel, Lisboa, p. 221-228.

TURISMO DE PORTUGAL (TP), (2015), Turismo 2020 Plano de Ação para o Desenvolvimento do Turismo em Portugal, Turismo de Portugal, Lisboa, [online]. 
TURISMO DE PORTUGAL (TP), (2017), Estratégia Turismo 2027, Turismo de Portugal, Lisboa, [online ].

TURISMO DE PORTUGAL (TP), (2018), Registo Nacional de Agentes de Animação Turística, Turismo de Portugal, Lisboa, [online].

UMBELINO J., BOAVIDA-PORTUGAL L., FERREIRA M. J., SOUSA J. F., (1993), O Inventário dos Recursos Turísticos de Portugal Continental, Inforgeo, no. 6, p. 93-99.

UNITED NATIONS WORLD TOURISM ORGANIZATION (UNWTO), (2017), Tourism highlights 2017, World Tourism Organization, Madrid, $15 \mathrm{p}$.

VIEIRA J. M., (1997), Economia do turismo em Portugal, Dom Quixote, Lisboa, 197 p.

WORLD ECONOMIC FORUM (WEF), (2017), The travel \& tourism competitiveness report 2017, World Economic Forum, Geneva, 370 p. [online].

WORLD TRAVEL \& TOURISM COUNCIL (WTTC), (2017), Travel \& tourism economic impact 2017 Portugal, World Travel \& Tourism Council, London, 19 p., [online].

\section{ABSTRACTS}

Portugal is an important tourist destination in Europe and the world. Tourism is one of Portugal's main socio-economic activities, with a highly satisfactory growth potential. The analysis of Portuguese tourism that is presented here spans the period 1965 to 2016 . It therefore sets out the main changes in tourism in Portugal over the last 50 years. The rise in tourist demand and the growing internationalization of destinations are emphasized, highlighting the importance of air transport, event organization and promotional campaigns. In terms of tourist destination structure, this article highlights the main tourist products and their consolidation over the period, the importance of education and training of human resources to ensure the quality of products and services, and the regional differentiation of tourist activity. Lastly, it presents a summary of the main tourist planning initiatives in Portugal in the last 50 years. The results show a marked increase in tourism supply and demand in the first 16 years of the twenty-first century, an increasing improvement of amenities and diversification of markets, not to mention a planning effort, yet an asymmetrical pattern persists in the national territory.

Le Portugal est une destination touristique importante, européenne et mondiale. Avec un énorme potentiel de croissance, le tourisme est l'une des principales activités socio-économiques du pays. L'analyse du tourisme au Portugal présentée ici démarre en 1965 et s'étend jusqu'en 2016. Elle couvre, par conséquent, les principales transformations du tourisme au Portugal au cours des 50 dernières années et met en évidence l'augmentation de la demande touristique et l'internationalisation croissante du tourisme, en soulignant l'importance du transport aérien, l'organisation d'événements et de campagnes promotionnelles. En ce qui concerne la structure de l'offre, cet article met l'accent sur les principaux produits touristiques et leur consolidation dans le temps, l'importance de l'éducation et de la formation des ressources humaines pour la qualification de l'offre et la différenciation régionale de l'activité. Pour finir, nous présentons une synthèse des principales initiatives de planification touristique au Portugal au cours des 50 dernières années. Les résultats montrent une forte croissance de l'offre et de la demande touristique au cours des 16 premières années du xxI siècle, une amélioration progressive de l'accueil et une diversification des marchés, ainsi qu'un effort de planification, en dépit de la persistance d'un modèle national asymétrique. 


\section{INDEX}

Geographical index: Portugal, Alentejo, Algarve, Azores, Lisbon, Porto, Guimarães

Keywords: tourism, destination management, airport, branding, golf, major events, cruises, World Heritage Sites

Mots-clés: tourisme, gestion de la destination, aéroport, l'image de marque, le golf, grands événements, croisières, Sites du Patrimoine Mondial

\section{AUTHOR}

\section{CLAUDETE OLIVEIRA MOREIRA}

Department of Geography and Tourism, University of Coimbra, Portugal Centre of Studies on Geography and Spatial Planning, CEGOT, Portugal, claudete@fl.uc.pt 